\title{
Role of Chlorella sp. and rhamnolipid 90 in maintaining homeostasis in soil contaminated with bisphenol A
}

\author{
Magdalena Zaborowska ${ }^{1}$ (D) Jadwiga Wyszkowska ${ }^{1}$ (D) Jan Kucharski ${ }^{1}$ (D)
}

Received: 18 February 2020 / Accepted: 27 July 2020 / Published online: 7 August 2020

(C) The Author(s) 2020

\begin{abstract}
Purpose The knowledge about the impact of BPA on soil health does not correspond to the great interest in its analogues. Therefore, a study was conducted to determine the potentially negative impact of BPA on the biochemical properties of soil. The study also evaluated the effectiveness of two biostimulants in eliminating potential homeostasis disorders caused by BPA.

Materials and methods A pot experiment was conducted under supervised conditions. BPA at five contamination levels was added to the soil of the granulometric composition of sandy loam at $0,0.1,2,40$ and $800 \mathrm{mg} \mathrm{BPA} \mathrm{kg}^{-1}$ of a dry matter (DM) of soil. The biochemical activity of the soil was interpreted through the activity of dehydrogenases (Deh), urease (Ure), catalase (Cat), acid phosphatase (Pac), alkaline phosphatase (Pal), arylsulphatase (Aryl) and $\beta$-glucosidase (Glu) whose activity was determined on days 5, 15 and 45 of the study. The biostimulative potential of Chlorella sp. and rhamnolipid 90 (which eliminates the undesirable effects of BPA on the parameters) was expressed with $\mathrm{IF}_{\mathrm{B}}$ - the factor of the impact of increasing of bisphenol (BP) soil contamination levels. The response of spring barley to increasing BPA pressure was analysed with the plant resistance index (RS). The study was made more comprehensive by determination of the macronutrient content in the plants.

Results and discussion The sensitivity of individual enzymes to increasing bisphenol pressure on the 45th day of the experiment can be arranged in the following sequence: Deh $>$ Ure $>$ Glu $>$ Pac $>$ Cat $>$ Aryl $>$ Pal. Biostimulation of soil with Chlorella sp. gave better results than with rhamnolipid 90. A compilation of BPA $800 \mathrm{mg} \mathrm{BPA} \mathrm{kg}{ }^{-1} \mathrm{DM}$ of soil and Chlorella sp. brought about an increase in the activity of Glu on the 45th day of the experiment and Pac, Pal and Aryl on the 5th day. Only at this contamination level did BPA stimulate the crop growth in all the parallel plots except in those biostimulated by Chlorella sp. Only algae significantly reduced the negative BPA impact on the N, Ca and K content in spring barley.

Conclusions The experiment emphasised the significant inhibitory impact of BPA on the biochemical activity of soil which, in consequence, upset the microbial balance of soil processes. Chlorella sp. played a more important role in maintaining the soil homeostasis than rhamnolipid 90, which did not correspond to its negative impact on the yield of spring barley.
\end{abstract}

Keywords BPA · Soil · Enzymes $\cdot$ Chlorella sp. · Rhamnolipid 90

Responsible editor: Huaiying Yao

Electronic supplementary material The online version of this article (https://doi.org/10.1007/s11368-020-02741-w) contains supplementary material, which is available to authorized users.

Jadwiga Wyszkowska

jadwiga.wyszkowska@uwm.edu.pl

Magdalena Zaborowska

m.zaborowska@uwm.edu.pl

Jan Kucharski

jan.kucharski@uwm.edu.pl

1 Department of Microbiology, University of Warmia and Mazury in Olsztyn, Plac Łódzki 3,-, 10-727 Olsztyn, Poland

\section{Introduction}

Bisphenol A (BPA) is regarded as the most widely produced chemical compound worldwide (Yu et al. 2015). The chemical structure of BPA is based on dihydroxybenzene with two hydroxyl groups in the para positions, which determines its good reactivity. BPA can be transformed into ethers, esters and salts and undergoes electrophilic substitution, such as sulphonation, alkylation and nitration (Flint et al. 2012). Moreover, its water-octanol coefficient in the logarithmic form ( $\log P=3.32$ ) indicates that it is readily soluble in fats and poorly soluble in water: ca. $200 \mathrm{mg} \mathrm{dm}^{-3}$ at $25{ }^{\circ} \mathrm{C}$ (Vandenberg et al. 2012). 
The global demand for BPA in 2015 amounted to approx. $7.70 \times 10^{9} \mathrm{~kg}$. Currently, the annual production output or import of BPA in the European Economic Area amounts to 1$10 \times 10^{9} \mathrm{~kg}$, and it is expected to increase to $10.60 \times 10^{9} \mathrm{~kg}$ by 2022 (Cydzik-Kwiatkowska et al. 2017; ECHA 2019). The greatest average increase in the global BPA production output is observed in India. It is associated with a $19 \%$ increase in demand for polycarbonates in this country (Bisphenol A 2016)

BPA is used in the production of multiple consumer goods (Guerra et al. 2015), including thermal paper, dental sealers (Pookpoosa et al. 2015), food containers, bottles and toys (Huang et al. 2012; Hu et al. 2019). BPA has also been reported as a semi-finished product in the manufacturing of dyes for fabrics (Xue et al. 2017). It is also widely used in the production of polyacrylate coats and can paints (Vandenberg et al. 2012). BPA analogues are degradation products of the pesticide-methoxychlor, used in some developing countries (Gupta et al. 2006). Bisphenol AF (a fluorinated BPA analogue) is synthesised as a monomer for partially fluorinated polycarbonates (Yang et al. 2014). Tetrabromobisphenol A (TBBPA) is referred to as a flame retardant in manufacturing electronic equipment (Wang et al. 2016). Copolyesters of AxPET/FxPET, with an addition of bisphenol $\mathrm{A}$ and bisphenol $\mathrm{F}$, have been found to be more thermostable and a better flame retardant than pure PET (De-Ming et al. 2015).

Increased BPA migration to the environment is caused, among others, by the production and processing of BPA and by polymer hydrolysis, which results in releasing BPA monomers to ecosystems and to food (Mercea 2009). According to Fenichel et al. (2013), BPA disrupts the oestrogen system, but also the function of androgens, prolactin, insulin and thyroid hormones. Through various cellular signalling pathways, BPA induces carcinogenesis and foetal malformations in the brain and the nervous system (Murata and Kang 2018). It is responsible for improper activation and AR-T877A mitogenesis in prostate cancer cells (Lee et al. 2003). In ovarian cells and breast cancer cells, it induces activation of protein kinase regulated by the $1 / 2$ signal (MARK/ERK1/2) (Song et al. 2015).

Growing concerns about BPA safety have been exacerbated by reports on the compound distribution in the environment. BPA is emitted to the atmosphere mainly as a result of industrial activities. These parameters are estimated at $100 \times$ $10^{9} \mathrm{~kg}$ annually. The highest average global BPA concentrations (4.55 $\mathrm{ng} \mathrm{m}^{-3}$ of air) were recorded in the urban regions of India, which corresponded to intensive burning of plastic products for household purposes (Fu and Kawamura 2010). Common use of BPA also contributed to the distribution of the compound in the aquatic environment, mainly by effluents from landfills and wastewater treatment plant discharges (Morin et al. 2015). Ultimately, it resulted in the contamination of freshwater and marine waters with this bisphenol
(Couderc et al. 2015). Rocha et al. (2013) found BPA in half of Portuguese rivers in concentrations ranging from 28.7 to $98.4 \mathrm{ng} \mathrm{BPA} \mathrm{dm}{ }^{-3}$ of water. Sewage sludge is also an important source of BPA (Flint et al. 2012). According to Song et al. (2014), the BPA detection rate for sludge in China was $76.9 \%$ and $97.5 \%$ in sludge in Korea, and it reached $100 \%$ in sludge in America (Lee et al. 2015; Yu et al. 2015). It must be stressed that bisphenols are more durable in sludge $\left(t_{1 / 2}=\right.$ $135-1621$ days) than in soil $\left(t_{1 / 2}=30-360\right)$ (Chen et al. 2016). Their degradation is correlated positively with the soil pH and TOC (Kalmykova et al. 2013). Bisphenol transformations in soil between the dissolved phase in soil and the colloidal phase are also affected by iron oxides (Urase and Miyashita 2003). Bisphenol interactions with elements of the soil environment are complex. Kwak et al. (2018) proposed critical value of BPA for protection of the soil ecosystem of $74.70 \mathrm{mg} \mathrm{kg}^{-1} \mathrm{DM}$ of soil using the species sensitivity approach. However, research in which the BPA toxicity for plants was determined even at the level of $1000 \mathrm{mg}$ BPA $\mathrm{kg}^{-1}$ DM of soil contamination (Kim et al. 2018) was conducted. One of the manifestations of its complex nature is the process of BPA glycosylation induced in plants, which produces secondary metabolites of mono- and di-O- $\beta$-dglucopyranosides without the oestrogen activity (Zaborowska et al. 2017; Nakajima et al. 2002).

Obviously, BPA biodegradation is also a consequence of bisphenol use by some bacteria as the only energy source, although they inhibit the growth of many strains (Kolvenbach et al. 2014). Two main mechanisms of BPA biodegradation occurring under aerobic conditions have been identified. The first is based on the oxidative rearrangement of the skeleton of an aliphatic methyl group in a bisphenol molecule. It has been shown for Cupravidus basilensis JF1 (Fischer et al. 2010). Sphingobium xenophagum is capable of metabolizing BPA by an ipso-substitution mechanism that involves ring hydroxylation at the site of the substituent (Gabriel et al. 2007). This is the second major BPA biodegradation pathway that involves the hydroxylation of one or two phenol rings followed by cleavage of the aromatic ring. It was demonstrated also for Sphingobium fuliginis OMI (Ogata et al. 2013). The diverse responses of microorganisms to BPA are caused by the expression of various genes: H6PD inducing the pentose phosphate pathway, CTH participating in the cysteine metabolic process, TRIM66 responsible for regulating transcription and PPP1R3E inducing the glycogen metabolism process (Yin et al. 2014). Pseudomonas aeruginosa has rhlC, rhlAB and PA1131 genes required for rhamnolipid synthesis (Bazire and Dufour 2014; Wittgens et al. 2017). According to Furmańczyk et al. (2017), Pseudomonas umsongensis has genes $\mathrm{rb} \mathrm{ADB}$ and $\mathrm{rfbC}$ which encode proteins responsible for the synthesis of rhamnolipid, which is a biosurfactant effective in hydrocarbon degradation and which facilitates their emulsification. It also produces a gene HHDH- 
$\mathrm{Pu}$ which encodes halohydrin dehalogenase, which is responsible for enzymatic opening of the epoxide ring (Xue et al. 2018). The aerobic catabolism of bisphenols is catalysed by monooxygenases, phenol hydroxylase, which adds one atom from an oxygen molecule to an aromatic ring, and toluene/oxylen monooxygenase (TOMO), capable of hydroxylation of more than one position of the aromatic ring (Cafaro et al. 2004). Furthermore, algae consume carbon dioxide for their growth, thereby inducing BPA transformation to derivatives of non-oestrogenic potential (Hirooka et al. 2005; Zaborowska et al. 2017).

To date, in-depth analyses have covered the microorganisms' BPA degradation potential rather than soil enzyme response to contamination of the soil environment with this compound, although soil enzymes are regarded as reliable indicators of soil biological quality representing their metabolic potential. However, the first reports have appeared on the impact of BPA, bisphenol S (BPS) and bisphenol F (BPF) analogues on soil biochemical and microbiological activity (Zaborowska et al. 2019, 2020a, b). BPS and BPF are considered less controversial substitutes for BPA harmful to humans. The premise for choosing BPS and BPF for research was the growing interest in these phenolic compounds. However, it does not correspond with the amount of research carried out on the impact of these bisphenols on the biochemical activity and response of soil microorganisms. It turned out that both BPS and BPF are potent inhibitors of both soil enzyme activity and the number and diversity of microorganisms. Therefore, the conducted experiment is an important complement to existing research, because there should be awareness of the differences in the BPA, BPS and BPF toxicity for both microorganisms and soil enzymes.

It was therefore regarded as reasonable to analyse the soil enzyme response, referred to as reliable soil quality indicators, to the pressure generated by increasing BPA levels. Preventive actions were also taken in order to offset the potential inhibitory action of bisphenol by soil biostimulation with Chlorella sp. and rhamnolipid 90. According to Ji et al. (2014), both Chlorella mexicana and Chlorella vulgaris can be used to treat the BPA-contaminated aquatic ecosystems. The high bioaccumulation and then the biodegradation rates of $24 \%$ are correlated with the content of fatty acids and carbohydrates. The potential of Chlorella sp. was determined mainly in soils contaminated with heavy metals (Nam et al. 2019). The impact of an algae in soils contaminated with bisphenols has not been studied so far. The choice of rhamnolipid 90 was dictated by the fact that, on the one hand, Pseudomonas aeruginosa produces rhamnolipid biosurfactants involved in numerous processes including removal of phenols and heavy metals from wastewater (Verma and Sarkar 2017), and on the other hand, metabolic pathways were identified, which are induced by Pseudomonas sp. and which effectively degrade bisphenols (Singh et al. 2018). The holistic nature of the study was achieved by determination of the impact of BPA on the growth and development of spring barley. Spring barley is the cereal with the fourth largest global production output, after maize, wheat and rice (Shen et al. 2016; FAOSTAT 2017), and it satisfies approx. 50\% of the demand for calories globally (OECD 2017). It also has relatively simple diploid genetics (Sreenivasulu et al. 2008), which increases its importance to science.

\section{Material and methods}

\subsection{Characteristics of BPA}

Bisphenol A (BPA) (synonyms: 4,4'-isopropylidenediphenol; 2,2-bis(4-hydroxyphenyl)-propane), a white, crystalline substance with a purity of $\geq 99.0 \%$ (HPLC) (Sigma Aldrich) was used in the experiment. Selected physical and chemical properties of BPA are presented in Table 1 (Hu et al. 2019; Michałowicz 2014).

\subsection{Soil material}

The experiment was conducted on soil collected from the Olsztyn Lake District situated in the north-east of Poland, within the province of the Eastern Baltic-Belarusian Lowland, which is part of the Eastern European Plain (NE Poland, 53.72 N, 20.42 E). Since it was the area of the Teaching and Experimental Centre in Tomaszkowo, the soil material before being collected was used as agricultural soil for cereal cultivation in accordance with the practices corresponding to the temperate warm transitional climatic zone in which the area is situated. Proper brown soil with the granulometric composition of sandy loam, determined in accordance with the IUSS Working Group WRB (2014), was collected from the genetic level Ap. Its physicochemical and biochemical parameters were determined by the methodology described by Borowik et al. (2017). Since $\mathrm{pH}$ in $1 \mathrm{Mol} \mathrm{dm}{ }^{-3} \mathrm{KCl}$ was $5.60, \mathrm{CaCO}_{3}$ in the amount sufficient to neutralise the hydrolytic acidity of 1.5 (HAC) was added to the soil on day 1 of the experiment. The other soil parameters were the following: hydrolytic acidity (HAC) $6.40 \mathrm{mM}(+) \mathrm{kg}^{-1} \mathrm{DM}$ of soil, base saturation (BS) $96.29 \%$, total base exchangeable cations (EBC) $165.90 \mathrm{mM}(+) \mathrm{kg}^{-1} \mathrm{DM}$ of soil, total organic carbon $\left(\mathrm{C}_{\text {org }}\right) 6.40 \mathrm{~g} \mathrm{~kg}^{-1} \mathrm{DM}$ of soil and total exchangeable cations: $\mathrm{K}^{+} 180, \mathrm{Na}^{+} 20, \mathrm{Ca}^{2+} 2571$ and $\mathrm{Mg}^{2+} 59.50 \mathrm{mg} \mathrm{kg}^{-1}$ DM of soil. Since the enzymatic activity and the granulometric composition are components of soil process simulation models, Table 2 presents the selected biochemical properties of the soil. 
Table 1 Determination of soil enzyme activity

\begin{tabular}{|c|c|c|c|c|c|}
\hline No. & Enzyme & Substrate & Unit/product & $\begin{array}{l}\text { Wavelength } \\
(\lambda) \mathrm{nm}\end{array}$ & References \\
\hline 1 & $\begin{array}{l}\text { Dehydrogenases } \\
\text { (EC 1.1) }\end{array}$ & $\begin{array}{l}\text { 2,3,5-triphenyl tetrazolium } \\
\text { chloride (TTC) }\end{array}$ & $\begin{array}{l}\mu \text { Mol triphenyl formazan } \\
\text { (TFF) } \mathrm{kg}^{-1} \text { of soil } \mathrm{h}^{-1}\end{array}$ & 485 & Öhlinger (1996) \\
\hline 2 & $\begin{array}{l}\text { Catalase } \\
\text { (EC 1.11.1.6) }\end{array}$ & $\mathrm{H}_{2} \mathrm{O}_{2}$-aqueous solution & $\begin{array}{l}\mathrm{Mol} \mathrm{O}_{2} \\
\mathrm{~kg}^{-1} \mathrm{DM} \text { of soil h}\end{array}$ & - & Alef and Nannipieri (1998) \\
\hline 3 & $\begin{array}{l}\text { Urease } \\
\text { (EC 3.5.1.5) }\end{array}$ & Urea -aqueous solution & $\begin{array}{l}{\mathrm{mMol} \mathrm{N}-\mathrm{NH}_{4}}_{\mathrm{kg}^{-1} \mathrm{DM} \text { of soil h}}^{-1}\end{array}$ & 400 & \\
\hline 4 & $\begin{array}{l}\beta \text {-Glucosidase } \\
\text { (EC 3.2.1.21) }\end{array}$ & 4-Nitrophenyl- $\beta$-D-glucopyranoside (PNG) & $\begin{array}{l}\text { mMol 4-nitrophenol (PN) } \\
\mathrm{kg}^{-1} \mathrm{DM} \text { of soil } \mathrm{h}^{-1}\end{array}$ & 410 & \\
\hline 5 & $\begin{array}{l}\text { Acid phosphatase } \\
\text { (EC 3.1.3.2) }\end{array}$ & $\begin{array}{l}\text { disodium-4-nitrophenylphosphate } \\
\text { hexahydrate (PNP) }\end{array}$ & & 400 & \\
\hline 6 & $\begin{array}{l}\text { Alkaline } \\
\text { phosphatase } \\
\text { (EC 3.1.3.1) }\end{array}$ & & & 400 & \\
\hline 7 & $\begin{array}{l}\text { Arylsulphatase } \\
\text { (EC 3.1.6.1) }\end{array}$ & Potassium-4-nitrophenyl -sulfate (PNS) & & 420 & \\
\hline
\end{tabular}

\subsection{Characteristics of biostimulants}

Chlorella sp. is unicellular green algae of class Trebouxiophyceae (Nam et al. 2019). The content of nitrate nitrogen $\left(\mathrm{NO}_{3}-\mathrm{N}\right)$ and ammonium nitrogen $\left(\mathrm{NH}_{4}{ }^{+}-\mathrm{N}\right)$ was $0.03 \mathrm{~g} \mathrm{~kg}^{-1} \mathrm{DM}$ and $9.81 \mathrm{~g} \mathrm{~kg}^{-1} \mathrm{DM}$, respectively. The macronutrients content expressed in $\mathrm{mg} \mathrm{kg}^{-1} \mathrm{DM}$ of Chlorella sp. was N 95.3, P 9.9, K 9.0, Mg 4.5 and Ca 4.7. Rhamnolipid 90
Table 2 Enzymatic activity in soil contaminated with BPA in the 5 th, 15 th and 45 th days of research, $\mathrm{kg}^{-1} \mathrm{DM}$ of soil $\mathrm{h}^{-1}$

\begin{tabular}{|c|c|c|c|c|c|c|c|}
\hline $\begin{array}{l}\text { Dose of BPA } \\
\left(\mathrm{mg} \mathrm{kg}^{-1}\right)\end{array}$ & $\begin{array}{l}\text { Deh } \\
(\mu \mathrm{Mol} \text { TFF })\end{array}$ & $\begin{array}{l}\text { Cat } \\
\left(\mathrm{Mol} \mathrm{O}_{2}\right)\end{array}$ & $\begin{array}{l}\mathrm{Pac} \\
(\mathrm{mMol}\end{array}$ & $\begin{array}{l}\text { Pal } \\
\text { nitrofenol PN) }\end{array}$ & Aryl & Glu & $\begin{array}{l}\text { Ure } \\
\left(\mathrm{mMol} \mathrm{N}-\mathrm{NH}_{4}\right)\end{array}$ \\
\hline \multicolumn{8}{|l|}{ 5th day } \\
\hline 0 & $1.39^{c}$ & $0.13^{\mathrm{c}}$ & $4.75^{\mathrm{c}}$ & $0.79^{\mathrm{a}}$ & $0.01^{\mathrm{b}}$ & $0.25^{\mathrm{a}}$ & $0.78^{\mathrm{a}}$ \\
\hline 0.1 & $1.46^{\mathrm{bc}}$ & $0.18^{\mathrm{ab}}$ & $4.84^{\mathrm{b}}$ & $0.68^{\mathrm{b}}$ & $0.02^{\mathrm{a}}$ & $0.29^{\mathrm{a}}$ & $0.45^{\mathrm{b}}$ \\
\hline 2 & $1.69^{\mathrm{b}}$ & $0.18^{\mathrm{a}}$ & $4.96^{\mathrm{a}}$ & $0.54^{\mathrm{c}}$ & $0.02^{\mathrm{a}}$ & $0.29^{\mathrm{a}}$ & $0.42^{\mathrm{b}}$ \\
\hline 40 & $1.68^{\mathrm{b}}$ & $0.16^{\mathrm{bc}}$ & $4.65^{\mathrm{d}}$ & $0.56^{\mathrm{c}}$ & $0.01^{\mathrm{b}}$ & $0.29^{\mathrm{a}}$ & $0.25^{\mathrm{c}}$ \\
\hline 800 & $2.31^{\mathrm{a}}$ & $0.15^{\mathrm{c}}$ & $4.68^{\mathrm{cd}}$ & $0.47^{\mathrm{d}}$ & $0.01^{\mathrm{c}}$ & $0.27^{\mathrm{a}}$ & $0.24^{\mathrm{c}}$ \\
\hline$r$ & $0.82 *$ & -0.14 & -0.40 & $-0.95^{*}$ & $-0.61 *$ & -0.41 & $-0.92^{*}$ \\
\hline \multicolumn{8}{|l|}{15 th day } \\
\hline 0 & $1.17^{\mathrm{d}}$ & $0.17^{\mathrm{bc}}$ & $4.57^{\mathrm{ab}}$ & $0.55^{\mathrm{c}}$ & $0.01^{\mathrm{b}}$ & $0.43^{\mathrm{a}}$ & $0.32^{\mathrm{ab}}$ \\
\hline 0.1 & $2.71^{\mathrm{b}}$ & $0.18^{\mathrm{b}}$ & $4.67^{\mathrm{a}}$ & $0.59^{\mathrm{c}}$ & $0.02^{\mathrm{b}}$ & $0.32^{\mathrm{b}}$ & $0.27^{\mathrm{ab}}$ \\
\hline 2 & $2.89^{\mathrm{b}}$ & $0.15^{\mathrm{c}}$ & $4.65^{\mathrm{a}}$ & $0.77^{\mathrm{a}}$ & $0.01^{\mathrm{b}}$ & $0.37^{\mathrm{ab}}$ & $0.24^{\mathrm{b}}$ \\
\hline 40 & $3.30^{\mathrm{a}}$ & $0.17^{\mathrm{bc}}$ & $4.56^{\mathrm{ab}}$ & $0.71^{\mathrm{b}}$ & $0.01^{\mathrm{b}}$ & $0.37^{\mathrm{ab}}$ & $0.31^{\mathrm{ab}}$ \\
\hline 800 & $1.77^{\mathrm{c}}$ & $0.29^{\mathrm{a}}$ & $4.46^{\mathrm{b}}$ & $0.78^{\mathrm{a}}$ & $0.02^{\mathrm{a}}$ & $0.36^{\mathrm{b}}$ & $0.35^{\mathrm{a}}$ \\
\hline$r$ & 0.32 & $0.64 *$ & $-0.64 *$ & $0.87 *$ & $0.57 *$ & -0.33 & 0.35 \\
\hline \multicolumn{8}{|l|}{ 45th day } \\
\hline 0 & $5.18^{\mathrm{a}}$ & $0.21^{\mathrm{b}}$ & $4.93^{\mathrm{bc}}$ & $0.69^{\mathrm{d}}$ & $0.01^{\mathrm{b}}$ & $0.37^{\mathrm{bc}}$ & $0.99^{\mathrm{b}}$ \\
\hline 0.1 & $4.62^{\mathrm{b}}$ & $0.15^{\mathrm{c}}$ & $5.07^{\mathrm{ab}}$ & $0.67^{\mathrm{d}}$ & $0.01^{\mathrm{b}}$ & $0.39^{\mathrm{b}}$ & $1.15^{\mathrm{a}}$ \\
\hline 2 & $4.61^{\mathrm{b}}$ & $0.16^{\mathrm{c}}$ & $5.15^{\mathrm{a}}$ & $0.72^{\mathrm{c}}$ & $0.01^{\mathrm{b}}$ & $0.45^{\mathrm{a}}$ & $0.82^{\mathrm{c}}$ \\
\hline 40 & $3.65^{\mathrm{d}}$ & $0.17^{\mathrm{c}}$ & $5.08^{\mathrm{ab}}$ & $0.7^{\mathrm{a} 9}$ & $0.01^{\mathrm{b}}$ & $0.34^{\mathrm{c}}$ & $0.79^{\mathrm{c}}$ \\
\hline 800 & $4.11^{\mathrm{c}}$ & $0.31^{\mathrm{a}}$ & $4.75^{\mathrm{c}}$ & $0.75^{\mathrm{b}}$ & $0.04^{\mathrm{a}}$ & $0.33^{\mathrm{c}}$ & $0.77^{\mathrm{c}}$ \\
\hline$r$ & $-0.85^{*}$ & $0.54 *$ & -0.34 & $0.81 *$ & $0.65^{*}$ & -0.40 & $-0.77 *$ \\
\hline
\end{tabular}

Homogeneous groups specified in columns, for each enzyme, depending on the increasing doses of BPA during the 5,15 and 45 days of experiment

Deh dehydrogenases, Cat catalase, Ure urease, Pal alkaline phosphatase, Pac acid phosphatase, Glu $\beta$-glucosidase, Aryl arylsulfatase, $r$ Pearson's linear correlation coefficient

*Significant for $P=0.05, n=14$ 
(No. CAS 869062-42-0) is a glycolipid synthesised by Pseudomonas aeruginosa, containing L-ramnose and $\beta$-hydroxy amphiphilic fatty acids (Sigma Aldrich). Its application rate is based on the critical concentration of rhamnolipid micelles (CMC) (Renfro et al. 2014).

\subsection{Design of pot experiment}

Analyses of soil enzyme responses to the pressure of increasing soil contamination with BPA have been scarce. Therefore, the choice of the method of conducting the experiment played a key role in obtaining reliable study results, unaffected by variables that could potentially modify the existing correlations. Therefore, the experiment was conducted under monitored conditions, in five replicates, on properly prepared soil material. Application to the soil of a sequence of experimental variables was preceded with soil fertilisation suitable for the specific crop. The form of fertilisation is described by Zaborowska et al. (2017) and the fertilisation rate, expressed as a pure nutrient, was N 250, P 50, $\mathrm{K} 90, \mathrm{Mg} \mathrm{20}, \mathrm{Cu} 5, \mathrm{Zn} 5$, Mo 5, Mn 5 and B 0.33 ( $\mathrm{mg} \mathrm{kg}^{-1}$ of soil). The potential inhibition was analysed based on four major factors: (1) the degree of soil contamination with BPA: 0, 0.1, 2, 40, $800 \mathrm{mg} \mathrm{BPA} \mathrm{kg}{ }^{-1} \mathrm{DM}$ of soil; (2) experiment duration depending on the crop growth phase: 5 days, 15 daystillering phase (BBCH 21 - beginning of the tillering phase: first tiller detectable), 45 days - heading phase (BBCH $52-20 \%$ of inflorescence emerged); (3) addition of potential biostimulants: rhamnolipid 90 (0 and $150 \mathrm{mg} \mathrm{kg}^{-1} \mathrm{DM}$ of soil) and Chlorella sp. (0 and $5 \mathrm{~g} \mathrm{~kg}^{-1} \mathrm{DM}$ of soil) and (4) method of soil use: unsown soil and soil sown with spring barley (Hordeum vulgare L.) var. Orphelia. A total of 45 combinations were analysed. The activity of soil enzymes was determined in soil samples taken from 15 research objects on days 5, 15 and 45 during the spring barley growth. The biostimulation scale of Chlorella sp. and rhamnolipid 90 was also determined in each of the three test dates. The tests were carried out in four replications. They also included uncontaminated BPA control objects. One kilogram of soil was packed into each polyethylene pot. Assumptions of the experiment performed under controlled conditions allowed monitoring of soil humidity that was kept at the level of $60 \%$ using distilled water. Day time ranged from $13 \mathrm{~h} 3 \mathrm{~min}$ to $16 \mathrm{~h} 31 \mathrm{~min}$. The average air temperature was $15.6{ }^{\circ} \mathrm{C}$, and air humidity was $76.5 \%$. In the next step, 15 seeds of spring barley were sown in selected pots, and after 9 days (BBCH 9 - coleoptile penetrates soil surface), five plants were left. Spring barley was harvested on day 45 , and its fresh and dry weights were determined as well as BPA content in the above-ground parts of the plants.

\subsection{Determination of soil enzyme activity}

The activity of seven enzymes: dehydrogenases, urease, catalase, acid phosphatase, alkaline phosphatase, arylsulphatase and $\beta$-glucosidase was determined in each soil sample in three replicates, by methods specified in Table 1 . The biochemical activity of the soil was determined with a Perkin-Elmer Lambda 25 spectrophotometer (Massachusetts, USA). Catalase was an exception; its main function at a high concentration of hydrogen peroxide is to participate in its decomposition to water and oxygen (Tehrani and Moosavi-Movahedi 2018). Therefore, its activity was determined by titration of hydrogen peroxide residue. The determinations were performed on days 5,15 and 45 of the experiment.

\subsection{Determination of the chemical composition and BPA residue in spring barley}

In order to analyse the crop response to the BPA pressure, the study involved determination of the content of macronutrients: $\mathrm{N}, \mathrm{P}, \mathrm{K}, \mathrm{Mg}$ and $\mathrm{Ca}$ in the dry weight of the spring barley above-ground parts and the BPA residue in pots contaminated with $800 \mathrm{mg} \mathrm{BPA} \mathrm{kg}^{-1} \mathrm{DM}$ of soil. The macronutrients were determined after oxidising wet pre-mineralisation with sulphuric acid $(98 \%)$. The Kjeldahl method $\left(\mathrm{N}_{\text {total }}\right)$ and the UV-VIS spectrophotometric method (P) with flame photometry $(\mathrm{K})$ and atomic absorption spectrometry (AAS) (Mg and Ca) were applied (Sivitskaya and Wyszkowski 2013). The BPA residue in barley was determined by gas chromatography coupled with tandem mass spectrometry on a Bruker Scion TQ "triple quadrupole" gas chromatograph and the monitoring of selected reactions (GC-MS/MS) following the sample ultrasound-aided extraction with acetonitrile and derivation with a mixture of N, O-bis(trimethylsilyl)trifluoroacetamide and 5\% trimethylchlorosilane. The determinations were performed at the measurement sensitivity of $0.1 \mathrm{mg} \mathrm{BPA} \mathrm{kg}{ }^{-1}$ DM of soil, ion source temperature $200{ }^{\circ} \mathrm{C}$, dosing temperature $280{ }^{\circ} \mathrm{C}$, ionization type $\mathrm{EI} 70 \mathrm{eV}$ and expansion factor $k=2$, with a $95 \%$ confidence level. The determinations were made at the PORT Institute Polish Center for Technology Development in Wroclaw.

\subsection{Computations and statistical analysis}

All of the statistical analyses were conducted with Statistica 10.0 software (StatSoft Inc. 2018). This experiment involved determination of the variance percentage of the variable under analysis $\left(\eta^{2}\right)$ defined by the analysis of variance - ANOVAand changes in the macronutrient $\mathrm{N}, \mathrm{P}, \mathrm{K}, \mathrm{Mg}$ and $\mathrm{Ca}$ content in the crop and the response of each enzyme to the soil contamination with BPA and biostimulation with the principal component analysis - PCA. Homogeneous variances between the enzymes were illustrated by Tukey's test (HSD) at $P=$ 0.01 , and the cluster method - a dendrogram by the Ward method - which grouped the enzymes with respect to their sensitivity to BPA. It was configured based on the BPA impact factor $\left(\mathrm{I}_{\mathrm{BP}}\right)$ calculated from the formula: 
$\mathrm{IF}_{\mathrm{BP} / \mathrm{b}(\mathrm{bC} / \mathrm{bR})}=\frac{\mathrm{A}_{\mathrm{BP} / \mathrm{B}}}{\mathrm{A}_{\mathrm{C}}}$

where

$\mathrm{IF}_{\mathrm{BP}}-$ the factor of the impact of increasing bisphenol (BP) soil contamination levels, $\left(\mathrm{IF}_{\mathrm{BP}}<1\right.$ - inhibition of the enzyme activity by $\mathrm{BPA}, \mathrm{IF}_{\mathrm{BP}}>1$ - stimulation of the soil enzyme activity by $\mathrm{BPA} ; \mathrm{A}_{\mathrm{BP}}$ - enzyme activity in the soil subjected to the increasing BPA contamination pressure; $\mathrm{A}_{\mathrm{C}}$ - activity of the enzyme in the control soil non-contaminated with BPA. The biostimulation potential of the Chlorella sp. and rhamnolipid 90 was determined using the $\left(\mathrm{IF}_{\mathrm{bC}(\mathrm{bR})}\right)$ index where $\mathrm{IF}_{\mathrm{bC}(\mathrm{bR})}$-factor of the Chlorella sp. $\left(\mathrm{IF}_{\mathrm{bC}}\right)$ and rhamnolipid's $90\left(\mathrm{IF}_{\mathrm{bR}}\right)$ impact, $\mathrm{IF}_{\mathrm{bC}(\mathrm{bR})}<1-$ Chlorella $\mathrm{sp}$. and rhamnolipid 90 inhibit the enzyme activity, $\mathrm{IF}_{\mathrm{bC}(\mathrm{bR})}>1-$ Chlorella sp. and rhamnolipid 90 stimulate the enzyme activity; $\mathrm{A}_{\mathrm{B}}$ - enzyme activity in the soil biostimulated with Chlorella sp. and rhamnolipid 90 and subjected to the increasing BPA contamination pressure; $\mathrm{A}_{\mathrm{C}}$-activity of the enzyme in the control soil and biostimulated with the Chlorella sp. and rhamnolipid 90.

Spring rape resistance (RS) to increasing BPA soil contamination was determined using the Orwin and Wardle's formula (2004) described by Zaborowska et al. (2019).

\section{Results}

\subsection{Activity of soil enzymes}

These analyses revealed a varied response of soil enzymes to increasing BPA pressure. The response of individual soil enzymes to bisphenol was reinforced by the analysis of variance (Fig. 1). The dose proved to be the test factor that had the greatest impact on the changes in Pac, Ure and Aryl activity, respectively: $15.28 \%, 8.16 \%$ and $7.30 \%$, as opposed to Deh $(0.05 \%)$. Furthermore, time was a significant moderator in transformations of Glu, Pac and Aryl, and $\eta^{2}$ above $20 \%$ were $46.84 \%, 32.31 \%$ and $23.05 \%$, respectively. Upsetting the biochemical balance on day 5 of the study resulted mainly from BPA inhibition with respect to Pal $(r=-0.949)$ and Ure $(r=$ $-0.917)$, which is indicated by the homogeneous groups corresponding to the correlation coefficients (Table 2). Fifteenday exposure to BPA contributed to stimulation of the Cat, Aryl and Deh activity. It must be emphasised that BPA at the lowest contamination level $\left(0.1 \mathrm{mg} \mathrm{kg}^{-1} \mathrm{DM}\right)$ induced twofold higher activity of dehydrogenases. An assessment of the soil homeostasis through Deh and Ure showed its considerable disruption on day 45 of the experiment, following the application of $40 \mathrm{mg} \mathrm{BPA} \mathrm{kg}{ }^{-1} \mathrm{DM}$ of soil. The enzyme activity decreased under their pressure by $30 \%$ and $20 \%$, respectively. The cluster analysis diagrams plotted by the Ward's method concerning the $\mathrm{I}_{\mathrm{BP}}$ index show the revealed relationships (Fig. 2a, b, c). The enzyme response to the highest contamination level of $800 \mathrm{mg} \mathrm{BPA} \mathrm{kg} \mathrm{DM}^{-1} \mathrm{DM}$ soil following 5 days of exposure to the bisphenol generated two clusters of homogeneous variances (Fig. 2a). Ure, Aryl and Pal (cluster I) and Deh, Pac, Cat and Glu (cluster II) were assigned to them. Lower values of $\mathrm{I}_{\mathrm{BP}}$ were calculated for the enzymes in cluster I. The diagram of biochemical transformations in the soil exposed to BPA for 15 days showed the different response of Deh to increasing soil contamination with BPA than the other enzymes (cluster III), although it emphasised the significant stimulation of Deh, Cat and Aryl in the soil exposed to a pressure of $800 \mathrm{mg} \mathrm{BPA} \mathrm{kg}{ }^{-1} \mathrm{DM}$ (cluster II) (Fig. 2b). The BPA impact index $\mathrm{I}_{\mathrm{BP}}$ values were high in these pots: $\mathrm{I}_{\mathrm{BP}}$ Deh $=1.582, \mathrm{I}_{\mathrm{BP}}$ Cat $=1.707, \mathrm{I}_{\mathrm{BP}}$ Aryl $=1.496$. The biotic stress caused by soil contamination with BPA for 45 days placed Ure, Deh and Glu in a separate cluster (II) of homogeneous variances, which is justified by the sensitivity of the enzyme to soil contamination levels exceeding $40 \mathrm{mg} \mathrm{BPA} \mathrm{kg}{ }^{-1} \mathrm{DM}$ (Fig. 2c). It is noteworthy that there is a separate subcluster (I) which shows the arylosulphatase response to the application of $800 \mathrm{mg}$ BPA $\mathrm{kg}^{-1} \mathrm{DM}$ of soil. The compilation of the time and bisphenol dose contributed to the Aryl $\mathrm{I}_{\mathrm{BP}}=2.646$.

\subsection{Biostimulation with Chlorella sp. and rhamnolipid 90}

High values $\left(\eta^{2}\right)$ for the extent of biostimulation with Chlorella sp. and rhamnolipid 90 of soil contaminated with BPA confirmed that this experimental factor is highly significant in biochemical transformations of the soil environment under study (Fig. 1). Biostimulation moderated the activity of all enzymes in the following sequence: Cat $(81.28 \%)>\mathrm{Pal}$ $(54.91 \%)>\operatorname{Deh}(47.03 \%)>\operatorname{Ure}(27.08 \%)>\operatorname{Aryl}(16.85 \%)>$ Pac $(10.23 \%)>$ Glu $(5.43 \%)$. The effectiveness of the substances used was determined with multidimensional PCA analysis (Figs. 3 and 4). The existing tendencies were determined with the biostimulation impact factor $\mathrm{IF}_{\mathrm{B}}$. The first variable explaining $44.91 \%$ of the total data variance clustered the ends of vectors corresponding to $\mathrm{IF}_{\mathrm{B} C h}$ for Deh, Ure, Pac, $\mathrm{Pal}$ and Cat. Furthermore, the variable explaining $21.18 \%$ of the variable variance induced the distribution of the ends of vectors for $\mathrm{IF}_{\mathrm{BCh}}$ for Glu and Aryl (Fig. 3). The case dislocation proved that Chlorella sp. effectively increased Glu activity in pots contaminated with 40 and $800 \mathrm{mg} \mathrm{BPA} \mathrm{kg}^{-1} \mathrm{DM}$ of soil on day 45 of the experiment. A compilation of the largest dose of BPA (800 mg kg-1 DM of soil) and Chlorella sp. on day 5 of the experiment stimulated the activity of Pac, Pal and Aryl and, likewise, the algae played their role in the soil under the pressure of the 20-times lower contamination with BPA, increasing the activity of Ure, Deh and Cat. The PCA also highlighted the range of BPA impact and biostimulation with rhamnolipid 90, which was effective for only 15 days of the 
Fig. 1 The share of independent variables in the evolution of the soil enzyme activity $\left(\eta^{2}\right)$ : $d$ dose of BPA, $b$ biostimulation, $t$ date of analysis, Deh dehydrogenases, Ure urease, Pac acid phosphatase, Pal alkaline phosphatase, Cat catalase, Aryl arylsulphatase, Glu $\beta$-glucosidase (three-way analysis of variance, ANOVA, at $P<0.05)$

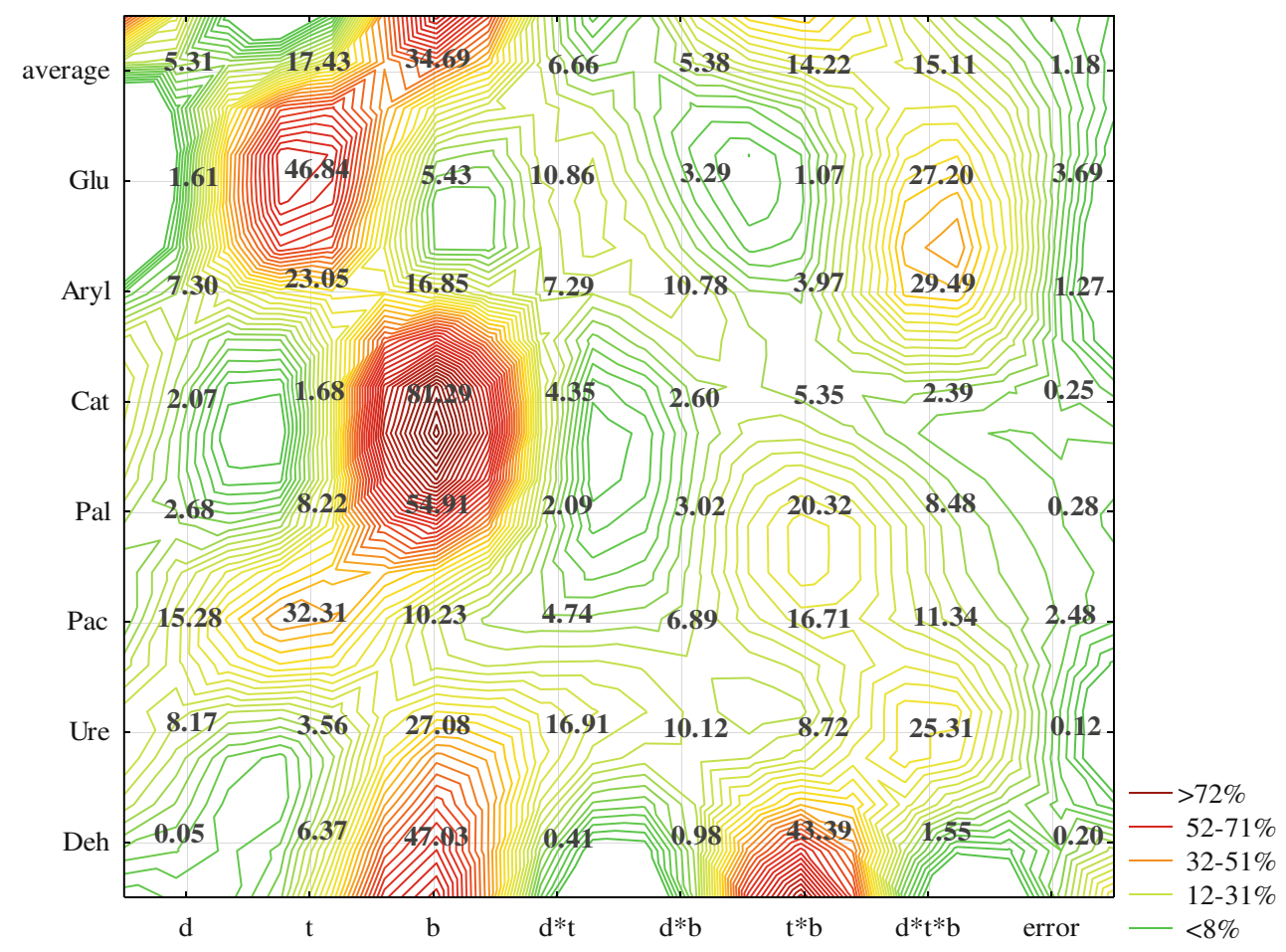

experiment (Fig. 4). This is demonstrated by the coordinates of cases and standardised vectors representing the $\mathrm{IF}_{\mathrm{BR}}$ and affected by the principal components PCA1 and PCA2. The first principal component generated negative values of vector ends for Aryl (-0.518) and Glu (-0.304) and the second principal component for Deh $(-0.459)$ and Pal $(-0.235)$. The biosurfactant contributed to a positive response of Deh to the highest level of contamination ( $800 \mathrm{mg} \mathrm{BPA} \mathrm{kg}^{-1} \mathrm{DM}$ of soil) after 15 days of exposure to bisphenol applied to the soil. Biostimulation of soil contaminated with $40 \mathrm{mg}$ BPA $\mathrm{kg}^{-1} \mathrm{DM}$ of soil also induced an increase in the activity of Cat, Ure and Pac (day 5 and 15) and Aryl and Glu (day 45).

\subsection{The effect of BPA on spring barley}

Since bisphenols are referred to as "priority substances" placed on ATSDR's Substances Priority List (ATSDR'S 2017) based on their toxicity and occurrence, it was important to verify as many factors as possible whose stable functions were disrupted by BPA. Therefore, the study characterised the spring barley resistance index to BPA in soil (Fig. 5). A negative correlation was found between the soil contamination with the bisphenol increasing to $40 \mathrm{mg} \mathrm{BPA} \mathrm{kg}{ }^{-1} \mathrm{DM}$ of soil and the crop resistance. Biostimulation with Chlorella sp. and rhamnolipid 90 did not bring any desired effects and even exacerbated the growth and development inhibition of spring barley in the case of algae. It is intriguing that the crop yield was significantly stimulated both in control pots with the highest level of contamination with BPA $\left(800 \mathrm{mg} \mathrm{kg}^{-1} \mathrm{DM}\right.$ of soil) and in parallel pots with rhamnolipid 90 . The study scope was expanded to include an assessment of the BPA impact on the macronutrient content in spring barley. It was performed by means of a principal component analysis (Fig. 6). The distribution of all the cases on the PCA map illustrated the beneficial impact of Chlorella sp. on the content of $\mathrm{N}, \mathrm{K}$ and $\mathrm{Ca}$ in a plant, which was not observed in the control pots or in those biostimulated with rhamnolipid 90 . This benefit is also demonstrated by positive values of the variable ends representing $\mathrm{N}, \mathrm{K}$ and $\mathrm{Ca}$ with respect to the second principal component (PCA2) describing $16.20 \%$ of variable variance.

\section{Discussion}

\subsection{Soil enzymes}

The sensitivity of the soil enzymes to increasing BPA pressure changed over the course of the experiment. On the 5 th day, the phenolic compound applied to the soil proved to be the most potent inhibitor of Pac, Ure and Aryl. On the 15th day, the inhibitory effects of BPA on Pac, Glu and, to a lesser extent, Deh were found. In turn, on the 45th day of the experiment, Deh, Ure and Glu proved to be the most sensitive to BPA. Biochemical activity is included in simulation models for soil processes, correlated with the organic matter decomposition rate (Wyszkowska et al. 2017; Kucharski et al. 2016). Dehydrogenases are regarded as a reliable bioindicator of xenobiotic toxicity (Campos et al. 2019). Soil dehydrogenases are reliable to indicate xenobiotic toxicity because they occur 
Fig. 2 Similarity of soil enzymes reaction to contamination of soil with BPA based on the coefficient of impact BPA ( $\left.\mathrm{I}_{\mathrm{BP}}\right)$ in 5th (a), 15 th (b) and 45th (c) day of research; Deh dehydrogenases, Cat catalase, Ure urease, Pal alkaline phosphatase, Pac acid phosphatase, Glu $\beta$-glucosidase, Aryl arylsulfatase; doses of BPA $\mathrm{mg} \mathrm{kg}^{-1}$ DM of soil: $0.1,2,40$, 800
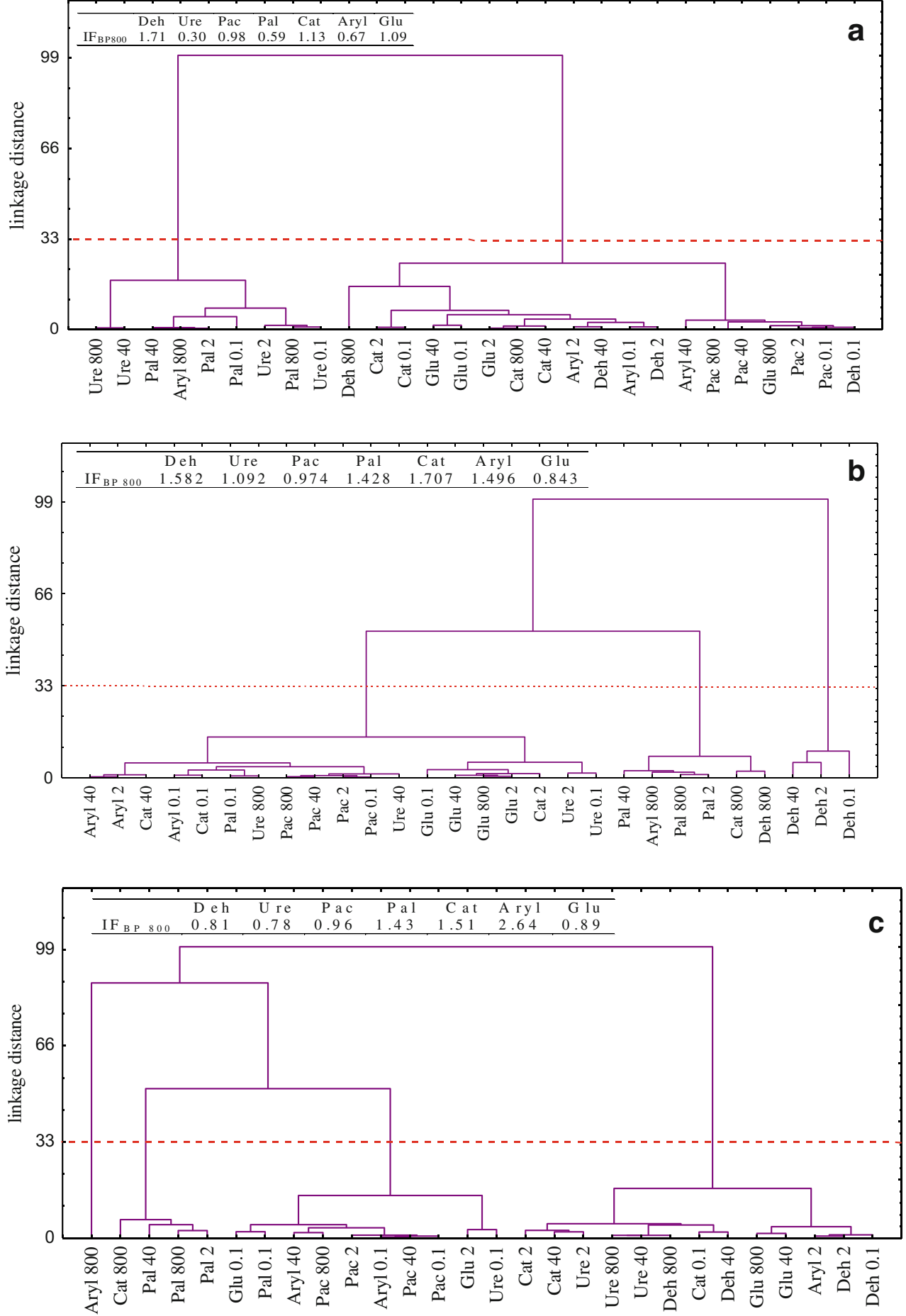

in all living cells of microorganisms. They are also characterized by a lack of ability to accumulate in the extracellular environment (Zhan et al. 2010). The fact that dehydrogenases carry out dehydrogenation or hydrogenation processes makes them relevant in the enzyme systems of all living microorganisms. In addition, soil dehydrogenases can use not only oxygen molecules as an electron acceptor but also other compounds that occur in the cells of anaerobic microorganisms
(Brzezińska et al. 2001). Since the study conducted by Zaborowska et al. (2019) found them to be the most sensitive to the pressure of bisphenol $\mathrm{S}$, which is a BPA analogue, a similar response was expected. On the other hand, dehydrogenases participate in the dehydrogenation of phenolic compounds and ethylbenzene conversion to 1 phenylethanol, and the ultimate acetophenone degradation to benzaldehyde and benzoic acid (Daudzai et al. 2018) which, 
Fig. 3 Coefficients of impact $\left(\mathrm{IF}_{\mathrm{bC}}\right)$ of Chlorella sp. for enzymes activity in soil contamination with BPA-PCA method; black square - the end of the vector of the primary variable: Deh dehydrogenases, Cat catalase, Ure urease, Pal alkaline phosphatase, Pac acid phosphatase, Glu $\beta$-glucosidase, Aryl arylsulfatase; black circle cases: doses of BPA mg kg-1 DM of soil: $0,0.1,2,40,800$; time: $I-5$ th day, $I I-15$ th day, $I I I-$ 45 th day of research

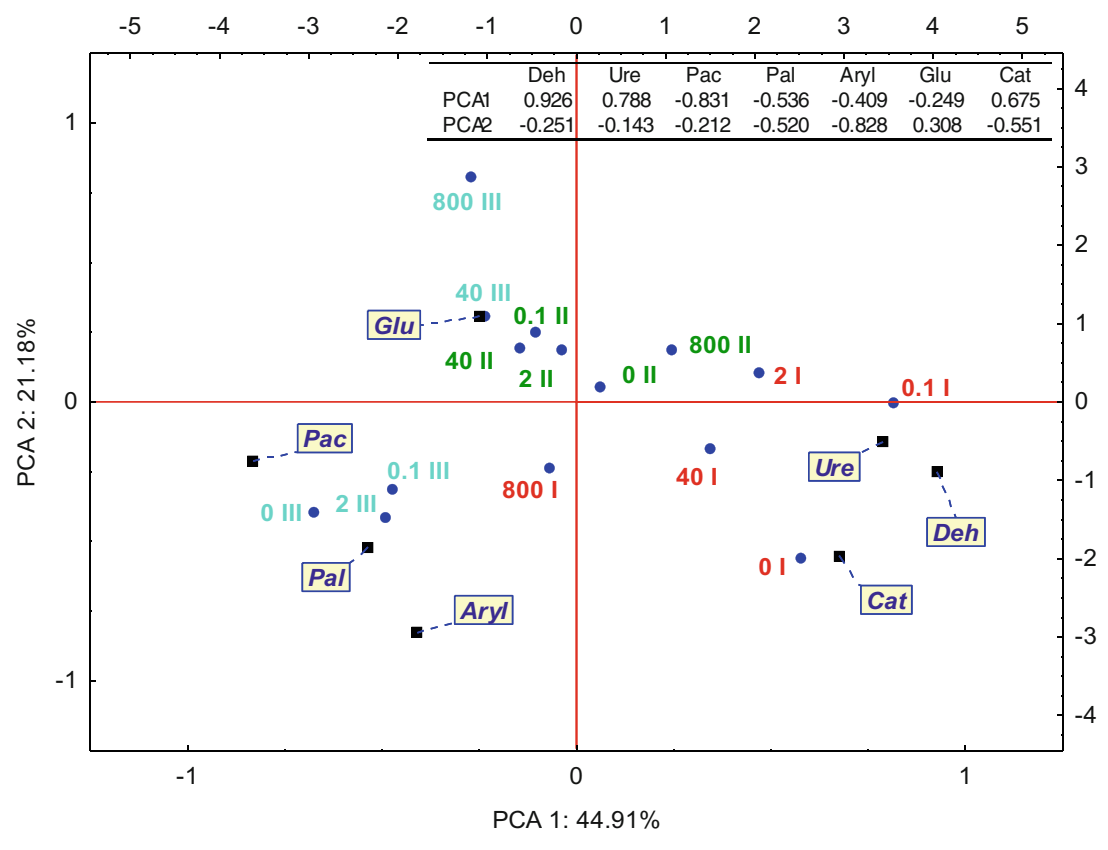

in turn, makes one put forward different hypotheses correlated to this study. Moreover, according to Herter et al. (2011), the intensity of phenolic compound inhibition is significantly affected by the presence and position of selected substituents. Researchers have put phenolic compound derivatives in the following sequence based on the extent of phenol oxidase activity stimulation: 2,6-dimethoxyphenol $>$ ABTS $>$ orthodihydroxylated compounds $>$ monoethoxylated monophenols $>$ dimethoxylated monophenols $>$ para-dihydroxylated compounds. A similar relationship was observed for urease. $\mathrm{N}^{1}, \mathrm{~N}^{2}$-diaryl derivatives containing nitro groups in phenyl rings exhibited low-protein urease inhibition (Perveen et al.
2008). Furthermore, organic compounds containing the methoxy group or hydroxy groups in the phenyl ring were found to be more toxic to urease (Mustafa et al. 2014; Rajic et al. 2009), which corresponds to the results of the current study. Khadem and Raiesi (2019) observed an opposite relationship. The presence of carboxyl and hydroxyl groups contributes to adsorption of alkaline phosphatase on soil colloids by interacting with amino groups in the enzyme molecules, thereby inducing its activation. Furthermore, the list of catalase inhibitors contains flavonoids (Krych et al. 2014). However, the peroxidatic pathway is induced at low concentrations of $\mathrm{H}_{2} \mathrm{O}_{2}$ in the soil environment, in which phenol
Fig. 4 Coefficients of impact $\left(\mathrm{IF}_{\mathrm{bR}}\right)$ of rhamnolipid 90 for enzymes activity in soil contaminated with BPA-PCA method (for abbreviations, see Fig. 5)

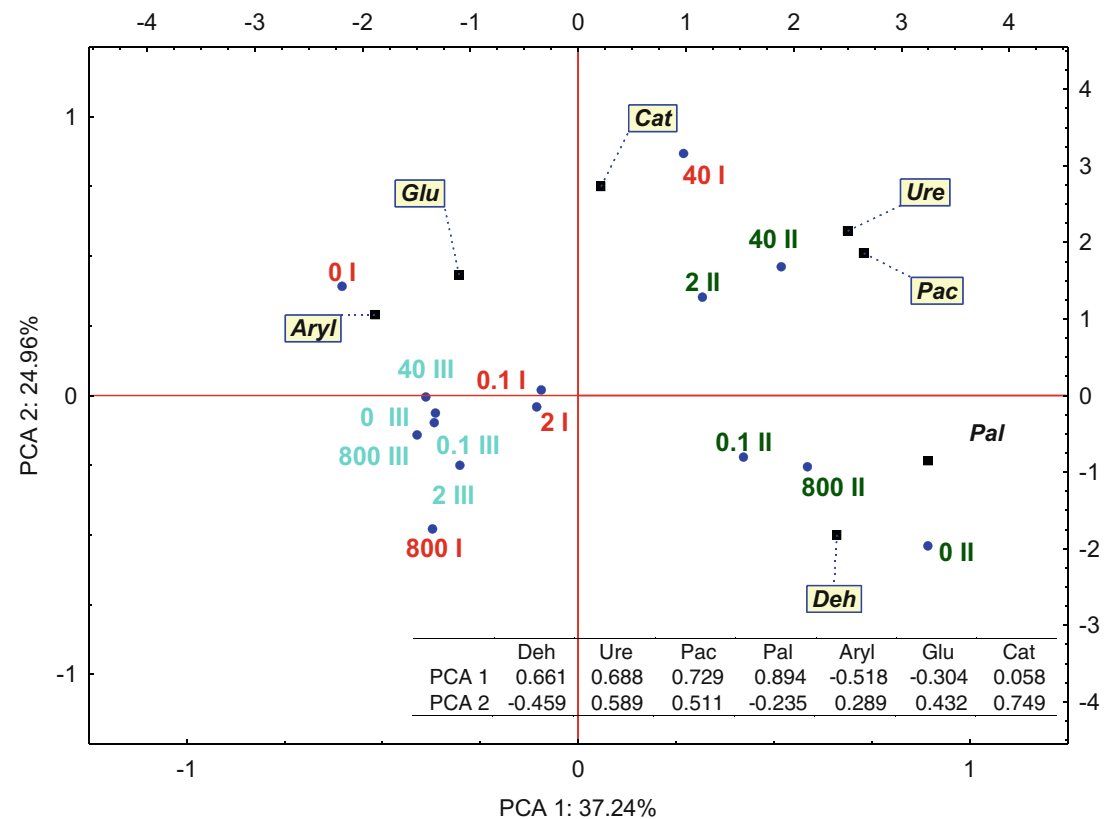


Fig. 5 The content of macronutrients $\mathrm{N}, \mathrm{P}, \mathrm{K}, \mathrm{Ca}, \mathrm{Mg}$ by spring barley (Hordeum vulgare L.) -PCA method; black square - the end of the vector of the primary variable; black circle cases: 0, 800 — doses of BPA kg-1

DM of soil, C control, $\mathrm{CH}$

Chlorella sp., R rhamnolipid 90

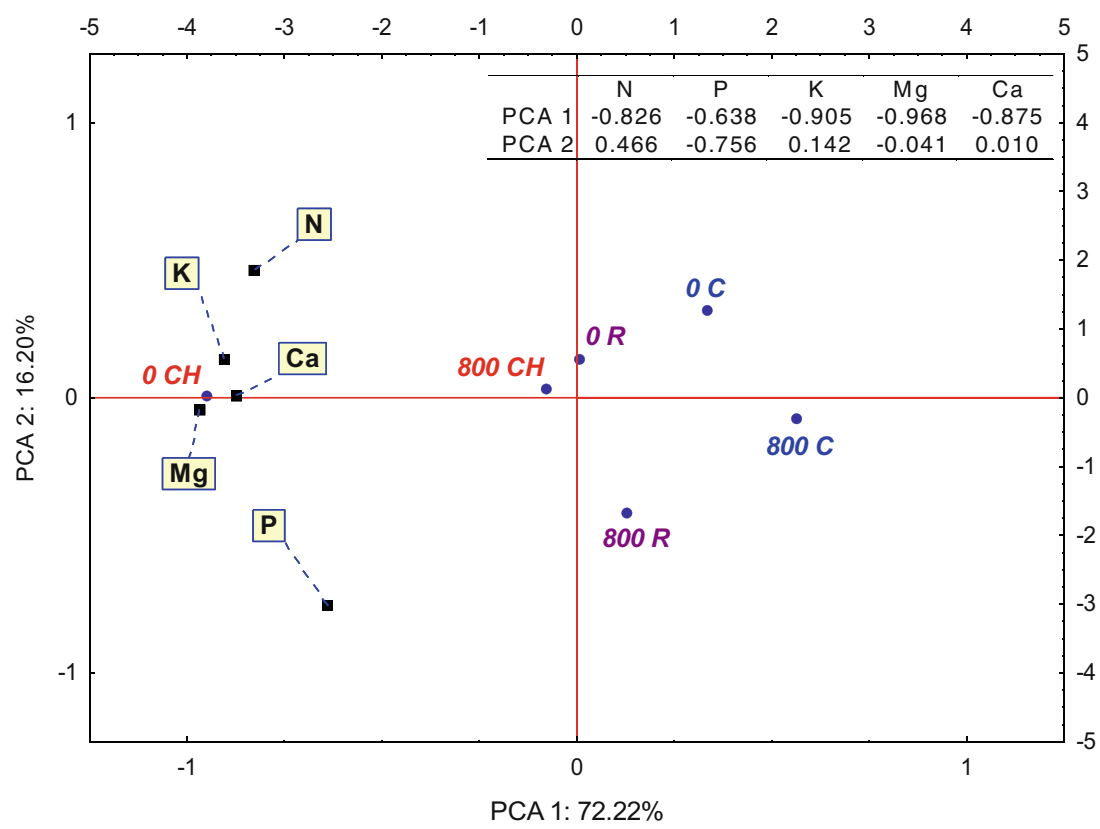

assumes the role of hydrogen peroxide and becomes the hydrogen donor (Hong et al. 2012).

It should also be taken into account that the functional viability of enzymes in mineral soils, as a result of reaction with minerals, lasts much longer in them than in organic soils (Schimel et al. 2017). In the soil environment, enzymes can also be stabilized by interactions with organic matter or metabolised by microorganisms. Repeatedly, soil enzymes undergo thermal denaturation (Burns et al. 2013). Organic compounds serving as food resource for microbes can coprecipitate with $\mathrm{Fe}$ or $\mathrm{Al}$ cations to form secondary mineral phases (Fe and $\mathrm{Al}$ oxyhydroxides) (Tamrat et al. 2019). In some cases, some microbes can access the organic compounds in organo-mineral associations, but it requires the secretion of specific enzymes whose affinity to the organic compounds is higher than its adsorption affinity (Basile-Doelsch et al. 2020). It should be emphasized that organic matter, $\mathrm{pH}$ and $\mathrm{Fe}$ oxides have the greatest impact on the exchange of organic chemical compounds between the soil solid phase and the solution phase. At the low $\mathrm{pH}$ value, the BPA removal rate decreases. In contrast, an increased BPA degradation efficiency was observed at high $\mathrm{pH}$ (Yu et al. 2019). Therefore, an example of
Fig. 6 Index of spring barley resistance (RS) depending on BPA contamination and biostimulation with Chlorella sp. and Rhamnolipid 90, 0.1, 2, 40, 800 - doses of BPA ( $\mathrm{mg} \mathrm{kg}^{-1}$ DM of soil) and content of BPA in spring barley $\left(\mathrm{mg} \mathrm{kg}^{-1} \mathrm{DM}\right.$ of barley); C control, CH Chlorella sp., $\mathrm{R}$ rhamnolipid 90

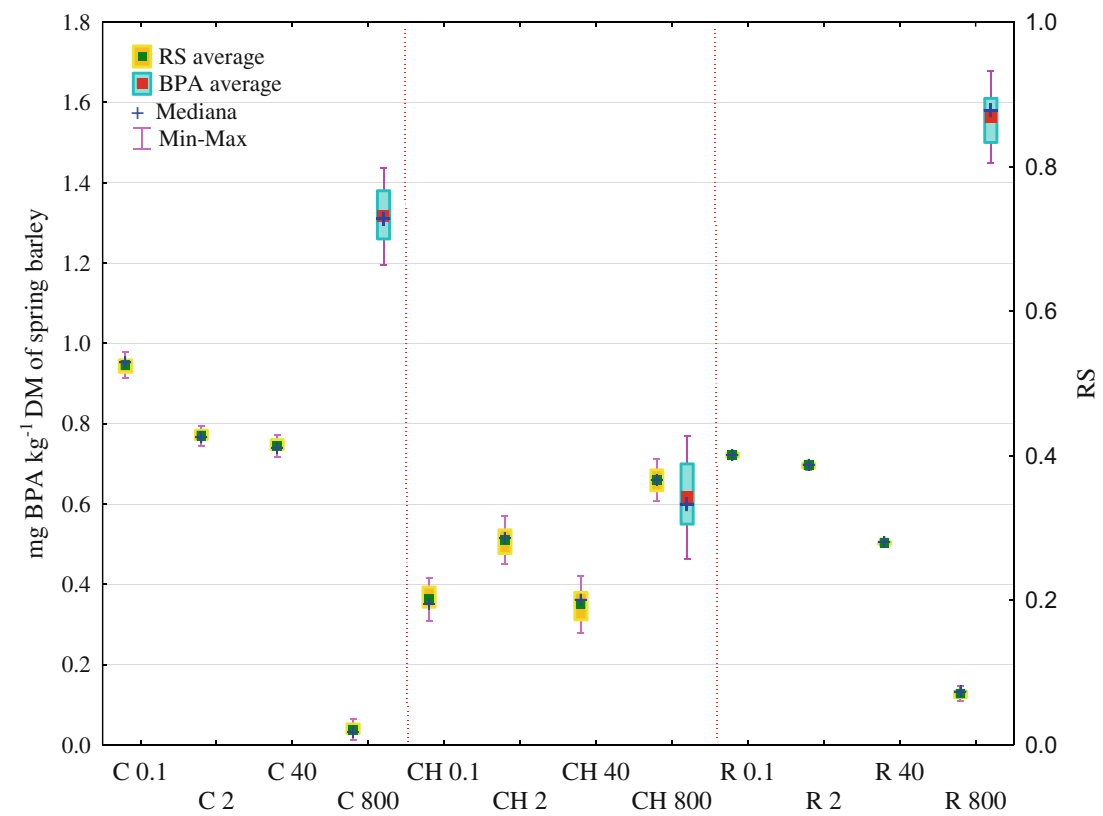


soils distinguished by a high content of bisphenols is peat soils, which are characterized by low $\mathrm{pH}$ value and the litter from peatland vegetation (Wiedermann et al. 2017).

\subsection{Biostimulation with Chlorella sp. and rhamnolipid 90}

The use of Chlorella sp. and rhamnolipid 90 brought the intended effect. Both rhamnolipid 90 and Chlorella sp. proved to be effective biostimulants of soil biochemical activity. However, Chlorella sp. enhanced the activity of individual enzymes more intensively. It contributed most to the increase of Glu, Ure, Deh and Cat activity in soil under pressure of 40 and $800 \mathrm{mg} \mathrm{BPA} \mathrm{kg}{ }^{-1} \mathrm{DM}$ whereas rhamnolipid 90 had a positive effect mainly on the activity of Deh, Aryl and Glu in soil contaminated with these doses of phenolic compound. According to the recent research (Nam et al. 2019), soil algae (including Chlorella sp.) are good bioindicators of soil quality. This can be regarded as an adverse process from the point of view of the accumulation of organic contamination in algae, which is the first step in biomagnification. However, when their potential for biostimulation of the soil biochemical activity is exploited, this property can be seen as an asset. Guo et al. (2017) demonstrated the presence of bound BPA residues defined as non-extractable. After only 10 days of exposure to bisphenol A, algae cells accumulated $15 \%$ of it, and the bioconcentration index for total radioactivity in algae was $106 \mathrm{~cm}^{3} \mathrm{~g}^{-1} \mathrm{DM}$ of algae, which indicates that the biostimulation was effective. On the other hand, algae themselves are an important source of bioactive compounds, including phenols, which have protective properties against abiotic and biotic stress (Onofrejová et al. 2010). A group of natural BPA metabolites in algae includes halogen derivatives of $p$ hydroxybenzoic acid, cinnamic acid ester (isopropyl $n$-butyl-3,5-dimethoxy-4-hydroxycinnamate) and florotannins (Hayat et al. 2002). The effectiveness of rhamnolipid 90 can be seen in that it replaces lipopolysaccharides in Pseudomonas aeruginosa, which protect them against organic contamination (Zorádová et al. 2011). Li et al. (2018) also demonstrated the adsorptive capability of this group of biosurfactants with respect to phenolic ions because of the benzene ring and polar hydroxyl groups in phenol molecules. According to Liu et al. (2012), the adsorptive capability increased with the soil environment $\mathrm{pH}$ between 2 and 7 and decreased in the $\mathrm{pH}$ range between 7 and 10. Rhamnolipid induced by Pseudomonas $\mathrm{Ph} 6$ changes the surface potential of the cell and its hydrophobic properties which, in turn, induces diffusion of hydrophobic organic compounds to cytochylems and their ultimate degradation (Zhong et al. 2008). As reported by
Ma et al. (2018), biodegradation was fostered by rhamnolipid doses of $\geq 100 \mathrm{mg} \mathrm{dm}^{-3}$.

\subsection{The effect of BPA on spring barley}

The reaction of spring barley to the increasing soil contamination by BPA was quite surprising. The resistance of a crop plant decreased with the increase of soil contamination by phenolic compound at the level of $40 \mathrm{mg} \mathrm{BPA} \mathrm{kg}{ }^{-1} \mathrm{DM}$ of soil. However, stimulation of spring barley growth was observed under pressure from the highest dose of $800 \mathrm{mg}$ BPA $\mathrm{kg}^{-1} \mathrm{DM}$ of soil. Although neither Chlorella sp. nor rhamnolipid 90 stimulated the growth of spring barley, Chlorella sp. exerted a beneficial effect on the content of N, $\mathrm{K}$ and $\mathrm{Ca}$ in the plant. Based on reports (Shah et al. 2017) on physiological and biochemical response of spring barley to elevated levels of $\mathrm{N}$, one could suppose that the response of $\mathrm{Ca}$ and $\mathrm{K}$ to a compilation of soil contamination with BPA and biostimulation with Chlorella sp. would be similar. Moreover, according to And and Wayne (2003), an elevated $\mathrm{Ca}^{2+}$ concentration in cytosol and $\mathrm{Ca}^{2+}$ binding with calmodulin $(\mathrm{CaM})$ is a result of barley response to biotic stress, which explains the relationship between the crop low resistance and an elevated concentration of $\mathrm{Ca}$ in pots with Chlorella sp. It is also noteworthy that $\mathrm{Ca}$ takes part in signal transduction for GABA, which initiates phenol accumulation in barley which, in turn, justifies the BPA content elevated in the above-ground parts of barley, as found in this study (Ma et al. 2019). It was found in a study conducted by Alobwede et al. (2019) that Chlorella sp. also contributed to an increase in the $\mathrm{N}$ content in the soil, which was not correlated with the crop yield. Therefore, the only controversy concerns the interaction between the highest applied dose of BPA $\left(800 \mathrm{mg} \mathrm{kg}^{-1} \mathrm{DM}\right.$ of soil), the $\mathrm{Mg}$ content and the spring barley yield. Chen et al. (2018) reported that a low Mg content leads to a decrease in chlorophyll biosynthesis by inhibition of expression of genes encoding the Mg-chelatin (ChlI) subunit and PPMT encoding Mg-protoporphyrin methyltransferase. Meanwhile, no disturbance in the barley yield was observed following the application of $800 \mathrm{mg}$ BPA kg${ }^{-1}$ DM of soil. However, one should not dismiss the fact that plants contain monooxygenases of cytochrome P450 (CYP8D1), which increase their resistance to organic contamination (Daudzai et al. 2018). Furthermore, the activity of biosurfactants can be moderated by phenolic compounds used preferentially as a source of carbon (PérezArmendáriz et al. 2013). This was probably the reason why the interaction of BPA at the highest dose and rhamnolipid 90 brought the desired result. At lower levels of contamination with bisphenol A, it may have been disrupted by rhamnolipid activity inhibitors, which include selected soil nitrogen sources, such as glutamine, asparagine or arginine (VenkataRamana and Karanth 1989). 


\section{Conclusions}

The experiment highlighted the negative impact of BPA on soil biochemical activity and, in consequence, disturbing the microbial balance of soil processes. The response of individual soil enzymes was varied. The duration of the experiment was an important moderator of soil enzymatic activity. On the 5th day, Pal turned out to be the most sensitive to BPA pressure. On the 15th day, scale of BPA inhibition was the largest for Pac. However, on the 45th day, BPA was proved to be the strongest Deh and Ure inhibitor. Chlorella sp. proved to be a better biostimulant of soil enzymatic activity than rhamnolipid 90. The use of Chlorella sp. caused an escalation of Glu activity on the 45th day of study, in soil contaminated with the highest dose of BPA $800 \mathrm{mg} \mathrm{kg}^{-1} \mathrm{dm}$ of soil, while rhamnolipid 90 slightly stimulated biochemical activity soil only for 15 days of the experiment.

The extent of the BPA inhibition as observed in this study corresponded with disorders of spring barley above-ground part growth, and biostimulation augmented the effect. The crop growth stimulation took place only after BPA at the dose of $800 \mathrm{mg} \mathrm{kg}^{-1} \mathrm{DM}$ of soil was applied in all the parallel pots, except in those biostimulated with Chlorella sp. Nevertheless, the algae were the only ones to significantly reduce the negative BPA impact on the N, Ca and $\mathrm{K}$ contents in spring barley.

Funding information This paper was financed by the University of Warmia and Mazury in Olsztyn (Poland) as part of topic No. 20.610.014-110 and cofinanced by the National Science Center (Project MINIATURA1).

The project was financially supported by Minister of Science and Higher Education in the range of the programme entitled "Regional Initiative of Excellence" for the years 2019-2022, Project No. 010/RID/ 2018/19, amount of funding 12.000.000 PLN."

\section{Compliance with ethical standards}

Conflict of interest The authors declare that they have no conflict of interest.

Open Access This article is licensed under a Creative Commons Attribution 4.0 International License, which permits use, sharing, adaptation, distribution and reproduction in any medium or format, as long as you give appropriate credit to the original author(s) and the source, provide a link to the Creative Commons licence, and indicate if changes were made. The images or other third party material in this article are included in the article's Creative Commons licence, unless indicated otherwise in a credit line to the material. If material is not included in the article's Creative Commons licence and your intended use is not permitted by statutory regulation or exceeds the permitted use, you will need to obtain permission directly from the copyright holder. To view a copy of this licence, visit http://creativecommons.org/licenses/by/4.0/.

\section{References}

Alef K, Nannipieri P (1998) Methods in applied soil microbiology and biochemistry. Academic Press, London, p 576
Alobwede E, Leake JR, Pandhal J (2019) Circular economy fertilization: testing micro and macro algal species as soil improvers and nutrient sources for crop production in greenhouse and field conditions. Geoderma 334:113-123. https://doi.org/10.1016/j.geoderma.2018. 07.049

And PKH, Wayne RO (2003) Calcium and plant development. Ann Rev Plant Biol 36(36):397-439

ATSDR (2017) Substance priority list. Atlanta, GA, U.S.A: Agency for Toxic Substances and Disease Registry. http://www.atsdr.cdc.gov/ $\mathrm{spl} /$

Basile-Doelsch I, Balesdent J, Pellerin S (2020) Reviews and syntheses: the mechanisms underlying carbon storage in soil. Biogeosci Discuss (in review). https://doi.org/10.5194/bg-2020-49

Bazire A, Dufour A (2014) The Pseudomonas aeruginosa rhlG and rhlAB genes are inversely regulated and $\mathrm{RhlG}$ is not required for rhamnolipid synthesis. BMC Microbiol 14:160. https://doi.org/10. 1186/1471-2180-14-160

Bisphenol A 2016 (BPA) Chemical Profile: Asia Phenol, (2016) https:// www.icis.com/resources/news/2016/06/30/10012759/chemicalprofile-asia-phenol/ (Last accessed on November 30, 2019)

Borowik A, Wyszkowska J, Wyszkowski M (2017) Resistance of aerobic microorganisms and soil enzyme response to soil contamination with ekodiesel ultra fuel. Environ Sci Pollut Res 24(31):2434624363. https://doi.org/10.1007/s11356-017-0076-1

Brzezińska M, Stępniewski W, Stępniewska Z, Przywara G (2001) Effect of oxygen deficiency on soil dehydrogenase activity in a pot experiment with Triticale cv. Jago vegetation. Int Agrophys 15:145-149

Burns RG, De Forest JL, Marxsen J, Sinsabaugh RL, Stromberger ME, Wallenstein MD, Weintraub MN, Zoppini A (2013) Soil enzymes in a changing environment: current knowledge and future directions. Soil Biol Biochem 58:216-234. https://doi.org/10.1016/j.soilbio. 2012.11.009

Cafaro V, Notomista E, Capasso P, Donato D (2004) Phenol hydroxylase and toluene/o -xylene monooxygenase from Pseudomonas stutzeri OX1: interplay between two enzymes. Appl Environ Microbiol 70(4):2211-2219

Campos JA, Peco JD, García-Noguero E (2019) Antigerminative comparison between naturally occurring naphthoquinones and commercial pesticides. Soil dehydrogenase activity used as bioindicator to test soil toxicity. Sci Total Environ 694(1):133672. https://doi.org/ 10.1016/j.scitotenv.2019.133672

Chen D, Kannan K, Tan H, Zheng Z, Feng YL, Wu Y, Widelka M (2016) Bisphenol analogues other than BPA: environmental occurrence, human exposure, and toxicity-a review. Environ Sci Technol 50(11):5438-5453. https://doi.org/10.1021/acs.est.5b05387

Chen ZC, Peng WT, Li J, Liao H (2018) Functional dissection and transport mechanism of magnesium in plants. Semin Cell Dev Biol 74: 142-152. https://doi.org/10.1016/j.semcdb.2017.08.005

Couderc M, Poirier L, Zalouk-Vergnoux A, Kamari A, Blanchet-Letrouv I, Marchand P, Venisseau A, Veyrand B, Mouneyrac C, Le Bizec B (2015) Occurrence of POPs and other persistent organic contaminants in the European eel (Anguilla anguilla) from the Loire estuary, France. Sci Total Environ 505:199-215. https://doi.org/10.1016/j. scitotenv.2014.09.053

Cydzik-Kwiatkowska A, Bernat K, Zielinska M, Bułkowska K, Wojnowska-Baryla I (2017) Aerobic granular sludge for bisphenol A (BPA) removal from wastewater. Int Biodeterior Biodegradation 122:1-11. https://doi.org/10.1016/j.ibiod.2017.04.008

Daudzai Z, Treesubsuntorn C, Thiravetyan P (2018) Inoculated Clitoria ternatea with Bacillus cereus ERBP for enhancing gaseous ethylbenzene phytoremediation: plant metabolites and expression of ethylbenzene degradation genes. Ecotoxicol Environ Saf 164:50-60. https://doi.org/10.1016/j.ecoenv.2018.07.121

De-Ming G, Xiang-Quan C, Liang T, Jia-Ning W, Teng F, Xiao-Lin W, Xiu-Li W, Li C, Yu-Zhong W (2015) PET-based copolyesters with bisphenol A or bisphenol F structural units: their distinct differences 
in pyrolysis behaviours and flame-retardant performances. Polym Degrad Stab 120:158-168. https://doi.org/10.1016/j. polymdegradstab.2015.07.001

ECHA 2019 Bisphenol A Registration Data. https://echa.europa.eu/ substanceinformation/-/substanceinfo/100.001.133

FAOSTAT (2017) available at http://www.fao.org/faostat/en/\#home. Accessed 28 Sept 2019

Fenichel P, Chevalier N, Brucker-Davis F (2013) Bisphenol A: anendocrine and metabolic disruptor. Ann Endocrinol 74:211-220. https://doi.org/10.1016/j.ando.2013.04.002

Fischer J, Kappelmeyer U, Kastner M, Schauer F, Heipieper HJ (2010) The degradation of bisphenol A by the newly isolated bacterium Cupriavidus basilensis JF1 can be enhanced by biostimulation with phenol. Int Biodeterior Biodegradation 64:324-330. https://doi.org/ 10.1016/j.ibiod.2010.03.007

Flint S, Markle T, Thompson S, Wallace E (2012) Bisphenol A exposure, effects, and policy: a wildlife perspective. J Environ Manag 104:19 34. https://doi.org/10.1016/j.jenvman.2012.03.021

Fu P, Kawamura K (2010) Ubiquity of bisphenol A in the atmosphere. Environ Pollut 158:3138-3143. https://doi.org/10.1016/j.envpol. 2010.06.040

Furmańczyk EM, Kamiński M, Dziembowski A, Lipiński L, Sobczak A (2017) Draft genome sequence of the type strain Pseudomonas umsongensis DSM 16611. Genome Announc 5:39

Gabriel FLP, Cyris M, Giger W, Kohler HPE (2007) Ipso-substitution: a general biochemical and biodegradation mechanism to cleave alphaquaternary alkylphenols and bisphenol A. Chem Biodivers 4(9): 2123-2137. https://doi.org/10.1002/cbdv.200790170

Guerra P, Kim M, Teslic S, Alaee M, Smyth SA (2015) Bisphenol-a removal in various wastewater treatment processes: operational conditions, mass balance, and optimization. J Environ Manag 152:192200. https://doi.org/10.1016/j.jenvman.2015.01.044

Guo R, Du Y, Zheng F, Wang J, Wang Z, Chen RJ (2017) Bioaccumulation and elimination of bisphenol a (BPA) in the alga Chlorella pyrenoidosa and the potential for trophic transfer to the rotifer Brachionus calyciflorus. Environ Pollut 227:460-467. https://doi.org/10.1016/j.envpol.2017.05.010

Gupta RK, Schuh RA, Fiskum G, Flaws JA (2006) Methoxychlor causes mitochondrial dysfunction and oxidative damage in the mouse ovary. Toxicol Appl Pharmacol 216:436-445. https://doi.org/10.1016/j. taap.2006.06.013

Hayat S, Atta-Ur-Rahman, Choudhary MI, Khan KM, Abbaskhan A (2002) Two new cinnamic acid esters from marine brown alga Spatoglossum variabile. Chem Pharm Bull 50:1297-1299. https:// doi.org/10.1016/j.taap.2006.06.013

Herter S, Schmidt M, Thompson M L, Mikolasch A, Schauer F (2011) Study of enzymatic properties of phenol oxidase from nitrogenfixing Azotobacter chroococcum. Herter et al. AMB Express 1:14. http://www.amb-express.com/content/1/1/14

Hirooka T, Nagate H, Uchida K, Hiroshige Y, Ehara Y, Nishikawa J, Nishihara T, Miyamoto K, Hirata Z (2005) Biodegradation of bisphenol $\mathrm{A}$ and disappearance of itsestrgenic activity by the green alga Chlorella fusca varvacuolata. Environ Toxicol Chem 24:18961901. https://doi.org/10.1897/04-259R.1

Hong J, Wang W, Huang K, Yang WY, Zhao YX, Xiao BL, Gao YF, Moosavi-Movahedi Z, Ghourchian H, Moosavi-Movahedi AA (2012) A highly efficient nano-cluster artificial peroxidase and its direct electrochemistry on a nanocomplex modified glassy carbon electrode. Anal Sci 28:711-716. https://doi.org/10.2116/analsci.28. 711

Hu Y, Zhu Q, Xueting Y, Liao C, Guibin J (2019) Occurrence, fate and risk assessment of BPA and its substituents in wastewater treatment plant: a review. Environ Res 178:108732. https://doi.org/10.1016/j. envres.2019.108732

Huang Y, Wong C, Zheng J, Bouwman H, Barra R, Wahlstrom B, Neretin L, Hong M (2012) Bisphenol A (BPA) in China: a review of sources, environmental levels, andpotential human impacts. Environ Int 42:91-99. https://doi.org/10.1016/j.envint.2011.04.010

IUSS Working Group WRB (2014) World Reference Base for soil resources: international soil classification system for naming soils and creating legends for soil maps. Rome, FAO

Ji MK, Kabra AN, Choi J, Hwang JH, Rae J, Reda K, Abou-Shanab A, Oh YK, Jeon BH (2014) Biodegradation of bisphenol A by the freshwater microalgae Chlamydomonas mexicana and Chlorella vulgaris. Ecol Eng 73:260-269. https://doi.org/10.1016/j.ecoleng. 2014.09.070

Kalmykova Y, Björklund K, Strömvall A M, Blom L (2013) Partitioning of polycyclic aromatic hydrocarbons, alkylphenols, bisphenol A and phthalates in landfill leachates and stormwater. Water Res 47: 1317 1328. https://doi.org/10.1016/j.watres.2012.11.054

Khadem A, Raiesi F (2019) Response of soil alkaline phosphatase to biochar amendments: changes in kinetic and thermodynamic characteristics. Geoderma 337:44-54. https://doi.org/10.1016/j. geoderma.2018.09.001

Kim D, Kwak JIL, An YJ (2018) Effects of bisphenol A in soil on growth, photosynthesis activity, and genistein levels in crop plants (Vigna radiata). Chemosphere 209:875-882. https://doi.org/10.1016/j. chemosphere.2018.06.146

Kolvenbach BA, Helbling DE, Kohler HE, Corvini PF (2014) Science direct emerging chemicals and the evolution of biodegradation capacities and pathways in bacteria. Curr Opin Biotechnol 27:8-14. https://doi.org/10.1016/j.copbio.2013.08.017

Krych J, Gebicki JL, Gebicka L (2014) Flavonoid-indbarluced conversion of catalase to its inactive forme compound II. Free Radic Res 48:1334-1341. https://doi.org/10.3109/10715762.2014.953139

Kucharski J, Tomkiel M, Baćmaga M, Borowik A, Wyszkowska J (2016) Enzyme activity and microorganisms diversity in soil contaminated with the boreal 58 WG. J Environ Sci Health B 51(7):446-454. https://doi.org/10.1080/03601234.2016.1159456

Kwak JL, Moon J, Kim D, Cui R, An YJ (2018) Determination of the soil hazardous concentrations of bisphenol A using the species sensitivity approach. J Hazard Mater 344:390-397. https://doi.org/10.1016/ j.jhazmat.2017.10.048

Lee HJ, Chattopadhyay S, Gong EY, Ahn RS, Lee K (2003) The xenoestrogen bisphenol A induces inappropriate androgen receptor activation and mitogenesis in prostatic adenocarcinoma cells. Toxicol Sci 75:40-46

Lee S, Liao C, Song GJ, Ra K, Kannan K, Moon HB (2015) Emission of bisphenol analogues including bisphenol a and bisphenol $\mathrm{F}$ from wastewater treatment plants in Korea. Chemosphere 119:1000 1006. https://doi.org/10.1016/j.chemosphere.2014.09.011

Li Y, Bi HY, Mao XM, Liang YQ, Li H (2018) Adsorption behavior and mechanism of core-shell magnetic rhamnolipid-layered double hydroxide nanohybrid for phenolic compounds from heavy metalphenolic pollutants. Appl Clay Sci 162(15):230-238. https://doi. org/10.1016/j.clay.2018.06.013

Liu Z, Zeng Z, Zeng G, Li J, Zhong H, Yuan X, Liu Y, Zhang J, Chen M, Liu Y, Xie G (2012) Influence of rhamnolipids and Triton X-100 on adsorption of phenol by Penicillium simplicissimum. Bioresour Technol 110:468-473. https://doi.org/10.1016/j.biortech.2012.01. 092

Ma Z, Liu J, Dick RP, Li H, Shen D, Gao Y, Waigi MG, Ling W (2018) Rhamnolipid influences biosorption and biodegradation of phenanthrene by phenanthrene-degrading strain Pseudomonas sp.Ph6. Environ Pollut 240:359-367. https://doi.org/10.1016/j.clay.2018. 06.013

Ma Y, Wang P, Gu Z, Tao Y, Shen C, Zhou Y, Han Y, Yang R (2019) $\mathrm{Ca}^{2+}$ involved in GABA signal transduction for phenolics accumulation in germinated hulless barley under $\mathrm{NaCl}$ stress. Food Chem: X 2:100023. https://doi.org/10.1016/j.fochx.2019.100023 
Mercea P (2009) Physicochemical processes involved inmigration of bisphenol A from polycarbonate. J Appl Polym Sci 112:579-593. https://doi.org/10.1002/app.29421

Michałowicz J (2014) Bisphenol A - sources, toxicity and biotransformation. Environ Toxicol Pharmacol 37(2):738-758. https://doi.org/ 10.1016/j.etap.2014.02.003

Morin N, Arp HPH, Hale SE (2015) Bisphenol A in solid waste materials, leachate water, and air particles from Norwegian waste-handling facilities: presence and partitioning behavior. Environ Sci Technol 49:7675-7683. https://doi.org/10.1021/acs.est.5b01307

Murata M, Kang JH (2018) Bisphenol A (BPA) and cell signaling pathways. Biotechnol Adv 36:311-327. https://doi.org/10.1016/j. biotechadv.2017.12.002

Mustafa S, Perveen S, Khan A (2014) Synthesis, enzyme inhibition and anticancer investigations of unsymmetrical 1,3-disubstituted ureas. J Serb Chem Soc 79(1):1-10. https://doi.org/10.2298/ JSC121212076M

Nakajima N, Ohshima Y, Serizawa S, Kouda T, Edmonds J, ,Shiraishi F, Aono M, Kubo A, Tamaoki M, Saji H, Morita M (2002) Processing of bisphenol A by plant tissues:glucosylation by cultured BY-2 cells andglucosylation/translocation by plants of Nicotiana tabacum. Plant Cell Physiol 43: 1036-1042. https://doi.org/10.1093/pcp/ pcf130

Nam SH, Lee J, An YJ (2019) Quantitative assessment of photosynthetic activity of Chlorella (Class Trebouxiophyceae) adsorbed onto soil by using fluorescence imaging. Environ Pollut 254:112942. https:// doi.org/10.1016/j.envpol.2019.07.110

OECD (2017) OECD-FAO Agricultural Outlook 2017-2026: Special focus: Southeast Asia. OECD Publishing, Paris, p 142

Ogata Y, Toyama T, Yu N, Wang X, Sei K, Ike M (2013) Occurrence of 4tert-butylphenol (4-t-BP) biodegradation in an aquatic sample caused by the presence of Spirodela polyrrhiza and isolation of a 4-t-BP-utilizing bacterium. Biodegradation 24:191-202. https://doi. org/10.1007/s10532-012-9570-9

Öhlinger R (1996) Dehydrogenases activity with the substrate TTC. In: Schinner F, Öhlinger R, Kandele E, Margesin R (eds) Methods in soil biology. Springer Verlag, Berlin, p 241

Onofrejová L, Va`sícková J, Klejdus B, Stratil P, Mišurcovác L, Krác`mar S, Kopecky J, Vaceka J (2010) Bioactive phenols in algae: the application of pressurized-liquid and solid-phase extraction techniques. J Pharm Biomed 51:464 470. https://doi.org/10.1016/j.jpba. 2009.03 .027

Orwin KH, Wardle DA (2004) New indices for quantifying the resistance and resilience of soil biota to exogenous disturbances. Soil Biol Biochem 36:1907-1912. https://doi.org/10.1016/j.soilbio.2004.04. 036

Pérez-Armendáriz B, Mauricio-Gutiérrez A, Jiménez-Salgado T, TapiaHernández A, Santiesteban-López, A (2013) Emulsification of hydrocarbons using biosurfactant producing strains isolated from contaminated soil in Puebla, Mexico. Biodegradation-Engineering and Technology. InTech Open Rijeka Croatia, p 25-45. https://doi.org/ $10.5772 / 56143$

Perveen S, Khan KM, Lodhi MA, Choudhary MI, Choudhary MI, Rahman A, Voelter W (2008) Urease and a-chymotrypsin inhibitory effects of selected urea derivatives. Lett Drug Des Discov 5:401405. https://doi.org/10.2174/157018008785777315

Pookpoosa I, Jindal R, Morknoy D, Tantrakarnapa K (2015) Occurrence and efficacy of bisphenol A (BPA) treatment in selected municipal wastewater treatment plants, Bangkok, Thailand. Water Sci Technol 72(3):463-471. https://doi.org/10.2166/wst.2015.232

Rajic Z, Perkovic I, Butula I, Zorc B, Hadjipavlou-Litina D, Pontiki E, Pepeljnjak S, Kosalec I (2009) Synthesis and biological evaluation of O-methyl and O-ethyl NSAID hydroxamic acids. J Enzym Inhib Med Chem 24(5):1179-1187. https://doi.org/10.1080/ 14756360902779128
Renfro TD, Xie W, Yang G, Chen G (2014) Rhamnolipid surface thermodynamic properties and transportin agricultural soil. Colloid Surface B 115:317-322. https://doi.org/10.1016/j.colsurfb.2013. 12.021

Rocha S, Domingues V, Pinho C, Fernandes V, Delerue-Matos C, Gameiro P, Mansilha C (2013) Occurrence of bisphenol A, estrone, $17 \beta$-estradiol and $17 \alpha$-ethinylestradiol in Portuguese rivers. Bull Environ Contam Toxicol 90:73-78. https://doi.org/10.1007/ s00128-012-0887-1

Schimel J, Becerra CA, Blankinship J (2017) Estimating decay dynamics for enzyme activities in soils from different ecosystems. Soil Biol Biochem 114:5-11. https://doi.org/10.1016/j.soilbio.2017.06.023

Shah JM, Bukhari SAH, ZeNg J, Xiao-yan Q, Ali E, Noor M, Guo-ping Z (2017) Nitrogen $(N)$ metabolism related enzyme activities, cell ultrastructure and nutrient contents as affected by $\mathrm{N}$ level and barley genotype. J Int Agric 16(1):190-198. https://doi.org/10.1016/ S2095-3119(15)61308-9

Shen Q, Fu L, Dai F, Jiang L, Zhang G, Wu D (2016) Multi-omics analysis reveals molecular mechanisms of shoot adaption to salt stress in Tibetan wild barley. BMC Genomics 17(1):889. https:// doi.org/10.1186/s12864-016-3242-9

Singh U, Arorab NK, Sachan P (2018) Simultaneous biodegradation of phenol and cyanide present in coke-oven effluent using immobilized Pseudomonas putida and Pseudomonas stutzeri. Braz J Microbiol 49:38-44. https://doi.org/10.1016/j.bjm.2016.12.013

Sivitskaya V, Wyszkowski M (2013) Changes in the content of some macroelements in maize (Zea mays L.) under effect of fuel oil after application of different substances to soil. J Elem 8:705-714

Song S, Song M, Zeng L, Wang T, Liu R, Ruan T, Jiang G (2014) Occurrence and profiles of bisphenol analogues in municipal sewage sludge in China. Environ Pollut 186:14-19. https://doi.org/10. 1016/j.envpol.2013.11.023

Song H, Zhang T, Yang P, Li M, Yang Y, Wang Y, Du J, Pan k, Zhang K (2015) Low doses of bisphenol A stimulate the proliferation of breast cancer cells via ERK1/2/ERR $\gamma$ signals. Toxicol in Vitro 30: 521-528. https://doi.org/10.1016/j.tiv.2015.09.009

Sreenivasulu N, Graner A, Wobus U (2008) Barley genomics: an overview. Int J Plant Genomics 48:6258-6213. https://doi.org/10.1155/ $2008 / 486258$

Statsoft Inc. (2018). Data analysis software system. Version 12.0. Available at: http://www.statsoft.com

Tamrat WZ, Rose J, Grauby O, Doelsch E, Levard C, Chaurand P, BasileDoelsch I (2019) Soil organo-mineral associations formed by coprecipitation of $\mathrm{Fe}, \mathrm{Si}$ and $\mathrm{Al}$ in presence of organic ligands. Geochim Cosmochim Acta 260:15-28. https://doi.org/10.1016/j. gca.2019.05.043

Tehrani HS, Moosavi-Movahedi AA (2018) Catalase and its mysteries. Prog Biophys Mol Biol 140:5-12. https://doi.org/10.1016/j. pbiomolbio.2018.03.001

Urase T, Miyashita K (2003) Factors affecting the concentration of bisphenol A in leachates from solid waste disposal sites and its fate in treatment processes. J Mater Cycles Waste Manag 5:0077-0082. https://oi.org/10.1007/s101630300012

Vandenberg L, Chahoud I, Heindel J, Padmanabhan V, Paumgartten F, Schoenfelder G (2012) Urinary, circulating, and tissue biomonitoring studies indicate widespread exposure to bisphenol A. Cien Saude Colect 17:407-434. https://doi.org/10.1289/ehp.0901716

Venkata-Ramana K, Karanth NG (1989) Factors affecting biosurfactant production using Pseudomonas aeruginosa CFTR-6 under submerged conditions. Chem Technol Biotechnol 45(1):249-257. https://doi.org/10.1002/jctb.280450402

Verma SP, Sarkar B (2017) Rhamnolipid based micellar-enhanced ultrafiltration for simultaneous removal of $\mathrm{Cd}(\mathrm{II})$ and phenolic compound from wastewater. Chem Eng J 319:131-1421. https://doi. org/10.1016/j.cej.2017.03.009 
Wang Y, Liu G, Hou X, Huang Y, Li C, Wu K (2016) Assembling gold nanorods on a poly-cysteine modified glassy carbon electrode strongly enhance the electrochemical response to tetrabromobisphenol A. Microchim Acta 183:689-696. https://doi. org/10.1007/s00604-015-1708-0

Wiedermann MM, Kane ES, Veverica TJ, Lilleskov EA (2017) Are colorimetric assays appropriate for measuring phenol oxidase activity in peat soils? Soil Biol Biochem 105:108-110. https://doi.org/10. 1016/j.soilbio.2016.11.019

Wittgens A, Kovacic F, Müller MM, Gerlitzki M, Santiago-Schübel B, Hofmann D, Tiso T, Blank LM, Henkel M, Hausmann R, Syldatk C, Wilhelm S, Rosenau F (2017) Novel insights into biosynthesis and uptake of rhamnolipids and their precursors. Appl Microbiol Biotechnol 101:2865-2878. https://doi.org/10.1007/s00253-0168041-3

Wyszkowska J, Boros-Lajszner E, Borowik A, Kucharski J, Baćmaga M, Tomkiel M (2017) Changes in the microbiological and biochemical properties of soil contaminated with zinc. J Elem 22(2):437-451. https://doi.org/10.5601/jelem.2016.21.2.1213

Xue J, Liu W, Kannan K (2017) Bisphenols, benzophenones, and bisphenol A diglycidyl ethers in textiles and infant clothing. Environ Sci Technol 51:5279-5286. https://doi.org/10.1021/acs. est.7b00701

Xue F, Ya X, Tong Q, Xiu Y, Huang H (2018) Heterologous overexpression of Pseudomonas umsongensis halohydrin dehalogenase in Escherichia coli and its application in epoxide asymmetric ring opening reactions. Process Biochem 75:139-145. https://doi.org/ 10.1016/j.procbio.2018.09.018

Yang Y, Li, Ning CJ, Yang Y (2014) Cloud point extraction for the determination of bisphenol A, bisphenol AF and tetrabromobisphenol A in river water samples by high performance liquid chromatography. Anal Methods 6:3285-3290

Yin R, Gu L, Li M, Jiang C, Cao T, Zhang X (2014) Gene expression profiling analysis of bisphenol A-induced perturbation in biological processes in ERNegative HEK293 cells. PLoS One 9(6):e98635. https://doi.org/10.1371/journal.pone.0098635

Yu X, Xue J, Yao H, Wu Q, Venkatesan AK, Halden RU, Kannan K (2015) Occurrence and estrogenic potency of eight bisphenol analogs in sewage sludge from the US EPA targeted national sewage sludge survey. J Hazard Mater 299:733-739. https://doi.org/10. 1016/j.jhazmat.2015.07.012

Yu Q, Feng L, Chai X, Qiu X, Ouyang H, Deng G (2019) Enhanced surface Fenton degradation of BPA in soil with a high $\mathrm{pH}$. Chemosphere 220:335-343. https://doi.org/10.1016/j. chemosphere.2018.12.141

Zaborowska M, Kucharski J, Wyszkowska J (2017) Brown algae and basalt meal in maintaining the activity of arylsulfatase of soil polluted with cadmium. Water Air Soil Pollut 228(8):1-13. https://doi. org/10.1007/s11270-017-3449-7

Zaborowska M, Wyszkowska J, Kucharski J (2019) Biochemical activity of soil contaminated with BPS, bioaugmented with a mould fungi consortium and a bacteria consortium. Environ Sci Pollut Res 26(36):37054-37069. https://doi.org/10.1007/s11356-019-06875-4

Zaborowska M, Wyszkowska J, Borowik A (2020a) Soil microbiome response to contamination with Bisphenol a, Bisphenol $\mathrm{F}$ and Bisphenol S. Int J Mol Sci 21:3529. https://doi.org/10.3390/ ijms 21103529

Zaborowska M, Wyszkowska J, Kucharski J (2020b) Soil enzyme response to bisphenol $\mathrm{F}$ contamination in the soil bioaugmented using bacterial and mould fungal consortium. Environ Monit Assess 192(1):20. https://doi.org/10.1007/s10661-019-7999-6

Zhan X, Wu W, Zhou L, Liang J, Jiang T (2010) Interactive effect of dissolved organic matter and phenanthrene on soil enzymatic activities. J Environ Sci 22:607-614. https://doi.org/10.1016/S10010742(09)60139-X

Zhong H, Zeng GM, Liu JX, Xu XM, Yuan XZ, Fu HY, Huang GH, Liu ZF, Ding Y (2008) Adsorption of monorhamnolipid and dirhamnolipid on two Pseudomonas aeruginosa strains and the effect on cell surface hydrophobicity. Appl Microbiol Biotechnol 79: 671-677. https://doi.org/10.1007/s00253-008-1461-y

Zorádová S, Dudáśová H, Lukácová L, Dercová K, Čertík M (2011) The effect of polychlorinated biphenyls (PCBs) on the membrane lipids of Pseudomonas stutzeri. Int Biodeterior Biodegrad 65:1019-1023. https://doi.org/10.1016/j.ibiod.2011.03.012

Publisher's note Springer Nature remains neutral with regard to jurisdictional claims in published maps and institutional affiliations. 